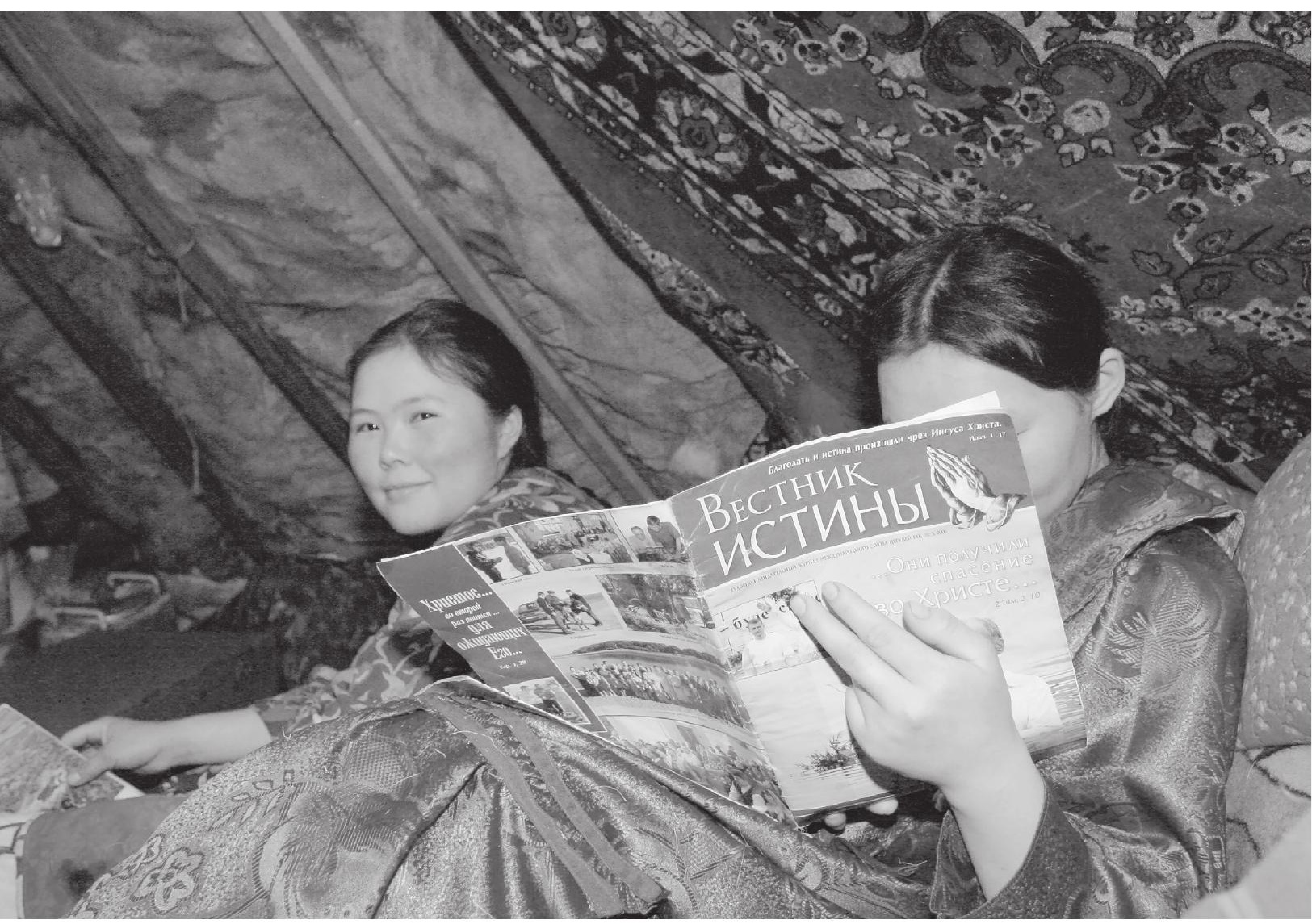




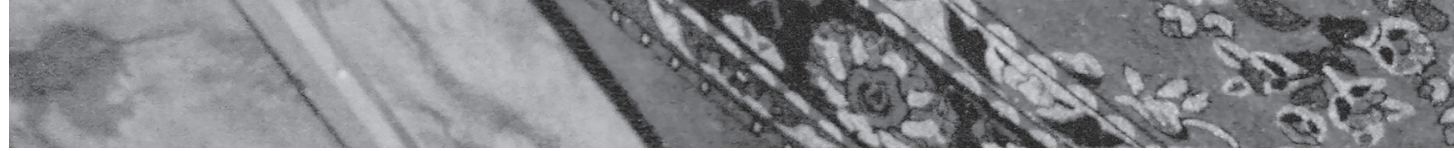

ERMi aastaraamat 61 (2018), Ik 154-181

DOI: $10.33302 /$ ermar-2018-007

\title{
Soome-ugri misjon: Eesti kristlaste hõimutöö Venemaal
}

\author{
Laur Vallikivi
}

\section{Sissejuhatus}

Nagu enamik päritolumüüte, nii on ka soome-ugri müüt produktiivne ja tegelikku elu kujundav. Kõige teravamalt väljendub see erinevates soome-ugri liikumise vormides, mis kätkevad endas poliitikat, teadust ja kunsti. Sellesse nimekirja tuleks lisada ka religioon, sealhulgas uuspaganlus ja kristlus. Kristlaste roll soome-ugri liikumises on jäänud vähestes olemasolevates soome-ugri liikumisi käsitlevates ülevaadetes vaatluse alt välja. Ometigi etendavad kristlased märkimisväärset osa uute suhtevõrgustike loomise, inimeste ja kogukondade muutmise, aga ka tekstide tõlkimise vahendusel. Need on tegevused, millega ka teised soome-ugri liikumised tegelevad, ainult et kristlaste jaoks on siin mängus teistsugune teleoloogia: soomeugri identiteedi ja kogukonna loomine ei ole eesmärk iseenesest, vaid see on vahend, et luua religioosset identiteeti ja kogukonda.

Käesoleva artikli ${ }^{1}$ eesmärk on anda esmane ülevaade kristluse rollist soome-ugri liikumises ja soome-ugri identiteedi instrumentaliseerimisest. Analüüsin Eestist (ja mõnevõrra ka Soomest) lähtuvat misjonitegevust soome-ugri (uurali) keeli kõnelevate rahvaste seas Venemaal. Toetun siinkohal ennekõike misjonäride kirjutistele, peamiselt Eestis väljaantavatele misjoniajakirjadele. Taustaks on mu enda välitööd vene ja ukraina protestantlike misjonäride poolt mõjutatud neenetsi põhjapõdrakasvatajate (Vallikivi 2005; 2009; 2011; 2014) ja kristlikust misjonist puutumata Kaama-taguste udmurtide seas (Toulouze, Vallikivi 2016). Mõlemas kogukonnas on esivanematelt pärandatud usundil ja keelel tähelepanuväärne roll, olgugi et noo-

[1] Artikkel on valminud Hõimurahvaste programmi projekt nr 782 toel. Tänan abi eest ka Nikolai Anisimovi, Anna Mišinat ja Eva Toulouze'i. Käesolev artikkel on lühendatud versioon artiklist „Des Finno-ougriens convertissent des Finno-ougriens: foi, parenté et langue dans la rencontre missionnaire" (Vallikivi 2018). Võõrkeelsete tsitaatide tõlked on minu. 
rem põlvkond on muutumas võrdselt kakskeelseks (sageli vene keel domineerib) ja üha vähem noori osaleb esivanematelt pärandatud mittekristlikel rituaalidel.

Artikli esimeses osas annan ülevaate soome-ugri keeli kõnelevatele rahvastele suunatud misjoni („hõimumisjon“, „hõimutöö“) kujunemisest ja seda kandvast ideoloogiast. Teises pooles keskendun Eesti ja Soome misjonäride tegevusele Venemaal ning kirjeldan lühidalt, kuidas on usukuulutajaid vastu võtnud ersad, mokšad, marid, udmurdid ning sürjakomid. Käsitlen muuhulgas ka protestantide suhteid Vene Õigeusu Kiriku (VÕK)² ning kohalike usundite esindajatega.

\section{Hõimumisjoni ajalugu}

Soome, ungari ja eesti luterlased tegid koostööd juba 1920.-1930. aastatel. Esimesed luteri vaimulike kogunemised, kus rõhutati hõimusidet, leidsid aset 1930. aastate lõpus. ${ }^{3}$ Tollane hõimuliikumine oli üsna erinev praegusest. Eesti riigi seisukohast oli see poliitiliselt oluline koostöövorm, mis hõlmas Eesti, Soome ja Ungari riiki. Palju tähelepanu pöörati väliseestlastele. Arusaadavalt olid Nõukogude Liidus elavate soome-ugri rahvastega kontaktid napid. Alles seejärel, kui Nõukogude Liit okupeeris Eesti, tekkisid Eesti luterlastel tihedamad kontaktid Venemaal elavate luterlastega, eriti ingerisoomlastega.

Nõukogude Liidu lagunemise järel asusid Eesti kristlased eri denominatsioonidest koostööd tegema põhjanaabritega, eriti Soome luterlike misjoniorganisatsioonidega, kes on Eestissegi saatnud oma misjonäre ja kes on ka peamised Eesti misjonäride rahastajad. 1993. aastal korraldasid Rootsi misjoniorganisatsioon Ljus $i$ Öster (Valgus idas), Soome nelipühi meediaorganisatsioon Avainsanoma (Võtmesõnum) ja Eesti Piibliselts esimese rahvusvahelise soome-ugri misjonikonverentsi Tartus. Sellega, nagu märgib Ljus $i$ Öster'i misjonisekretär Rauli Lehtonen, algas „Eesti ja Põhjamaade üldkristlik hõimumisjon" (HA 2016 (16): 5). Osalejaid oli seal Eestist, Soomest, Rootsist, Rumeeniast, Ukrainast, Ungarist ja Venemaalt (Marimaalt, Udmurtiast, Baškiiriast). Sel korral tehti ka otsus algatada misjoni- ja piiblikool, mille eesmärk oli koolitada misjonäre („töötegijaid“) Uurali ja Volga piirkonna „evangeliseerimata rahvastele“ (HA 2016 (16): 5). Esimene koolitus toimus samal aastal Udmurtias (HA 2006 (1): 15; 2007 (2): 11). ${ }^{4}$

[2] Teise nimega Moskva Patriarhaat.

[3] Enne Teist maailmasõda jõudis toimuda kaks luterlike vaimulike konverentsi. Nüüdseks on neid toimunud 13 korda: Budapest 1937, Lappeenranta 1939, Budapest 1968, Iisalmi 1981, Budapest 1985, Valkeala 1989, Otepää 1993, Budapest 1996, Lapua 2000, Kolozsvár (ClujNapoca) 2004, Révfülöp 2008, Tartu 2012, Petroskoi 2016. Esimestel kordadel kohtusid vaid soome, ungari ja eesti vaimulikud. Eesti vaimulikud ei saanud osaleda 1968. aasta Budapesti konverentsil ja Venemaa esindajad (Ingeri Evangeelne Luterlik Kirik) liitusid alles 1996. aastal (HA 2012 (8): 17; Kaldur 2016).

[4] Rauli Lehtonen annab ülevaate piiblikoolidest 2016. aasta seisuga: „Tänaseks on soomeugri piiblikoole korraldatud üle 20 korra, seal on õppinud üle 550 õpilase Uurali ja Volga piirkonna eri aladelt. Koolituse eest on põhivastutust kandnud Ljus i Öster. Mitmel aastal on kooli eestvedajaks olnud Eesti Metodisti Kiriku Teoloogiline Seminar Mark Nelsoni juhatusel. Soome-ugri konverentse on traditsiooniliselt korraldatud 2-3 aasta järel, sealhulgas 
Institutsionaalselt kujuneb eestlaste idasuunalisest misjonist ajapikku välja tervet hulka konfessioone ja organisatsioone ühendav ettevõtmine. Aastal 2000 loodi Eesti Evangeelne Allianss. See koondab erinevaid protestantlikke liikumisi (metodistid, nelipühilased, luterlased, baptistid, vabakogudused jne) eesmärgiga koordineerida misjonitegevust. 2005. aasta lõpus tekkis uus algatus, mis hakkas kandma nime „Hõimurahvaste Aeg“. 5 Samanimelist ajakirja hakati välja andma alates 2006. aastast. Esimese numbri avatekstis kirjutatakse:

Tänu teie abile on võimalik jätkata piiblitõlget soome-ugri keeltesse, koolitada töötegijaid, saata välja uusi misjonigruppe ning toetada hõimurahvaste keskel teenivaid misjonäre (HA 2006 (1): 4).

Klassikalise misjoniajakirjana tutvustab see misjonitööd ja kutsub üles annetama, toetama ja osalema. Annetajatele saadetakse ajakiri koju.

\section{Jumalast antud nišš}

Järgnevalt analüüsin protestantide diskursust soomeugrilusest ja hõimuliikumisest, toetudes ajakirjale Hõimurahvaste Aeg ja teistele kristlikele väljaannetele. Üks Eestis misjonitöö korraldamise eestvedajaid on metodist Mark Nelson, kes on Eestis elav kanadalane. ${ }^{6}$ Ta kirjutab rahvusvahelisele auditooriumile suunatud kristlikus väljaandes The East-West Church $\mathcal{E}$ Ministry Report, kuidas ta koges ühes pisikeses Mordva külakoguduses soome-ugri sugulust ja eestlaste erilist võimalust misjonitööks:

Teades, et olen sündinud Kanadas, tutvustas kohalik luterlik pastor mind nii: "Kas olete kunagi näinud tõelist elus ameeriklast?" (Sellist üldistust talun ma vastumeelselt.) See tutvustus tõi uudishimulikud naeratused lähima linna Saranski venelaste näole, kuna olin esimene põhjaameeriklane, keda nad olid kohanud. Mordva külas peegeldus inimeste nägudelt vastu aga täielik ükskõiksus. Ma vastasin, et olen küll sündinud Kanadas, aga kolisin rohkem kui kümne aasta eest Eestisse ja et mu naine ja lapsed on eestlased ning mu kodu on nü̈̈d Eestis. Selle peale lõid mordvalaste näod särama: "Eesti! Me oleme sugulased!“ Selliseid lugusid võib korrata iga eestlane, kes rändab nende arvukate etniliste rühmade seas Venemaal. Udmurtias, mis asub seitsesada miili Moskvast ida pool, embas mind vanem udmurdi memm ja ütles: "Me oleme perekond. Me ei ole aga üksteist näinud kümme tuhat aastat." Sel hetkel ei tahtnud ma talle pettumust valmistada ning öelda, et tegelikult on hoopis mu naine eestlane

Tartus, Budapestis, Solnas, Tamperes, Iževskis, Sõktõvkaris, Joškar-Olas, Tallinnas ja Stockholmis. Koostöö üldkirikliku loomu tõttu on usklikud saanud ühiselt panustada näiteks piiblitõlkimisse, misjonireisidesse ja rahvuslike töötegijate toetamisse, mis on olulised nii nelipühi, baptisti, metodisti kui ka luterlikele kogudustele“ (HA 2016 (16): 5).

[5] Sellesse on kaasatud protestantlikud ühendused Eesti Piibliselts, Eesti Evangeelse Alliansi Evangelismi- ja Misjonitoimkond, Eesti Evangeelse Luterliku Kiriku Misjonikeskus ning Ljus $i$ Öster, vt http://hoimurahvad.misjon.ee/ (viimati külastatud 30.11.2017).

[6] Mark Nelson on ka Eesti Metodisti Kiriku Teoloogilise Seminari dekaan ning süstemaatilise teoloogia ja piibliõppe lektor. Samuti õpetab ta Eesti Metodisti Kiriku Piiblikoolis ja korraldab soome-ugri rahvaste esindajatele mõeldud piiblikoole Venemaal ja Eestis. 
ja mitte ma ise. Need vennalikud tunded on vägagi tõelised ja loovad erakordse võimaluse misjoni tegemiseks. (Nelson 2009)

Seda, et eestlased räägivad sugulusest emotsionaalselt, kajastab näiteks eestlase Kaupo Kanti meenutus, kes on samuti metodist:

Minu esimene külaskäik Udmurtiasse ja koos sealsete kristlastega läbielatud imelised kogemused veensid mind, et meil, eestlastel, on eriline ja samas alandlikukstegev võimalus kuulutada Jeesuse vabastavat ja jõuduandvat nime üllatavalt lähedastele sugulastele (HA 2009 (4): 19).

Sarnaseid tõdemusi leidub misjoniajakirja Hõimurahvaste Aeg veergudel teisigi. Nendes tsitaatides peegelduvad kesksed misjonäre innustavad ideed. Olulisim sõnum on see, et emotsionaalset soome-ugri sugulustunnet tuleb ära kasutada: see on erakordne võimalus mõlemale osapoolele. Ühelt poolt annab see eestlastele (ja soomlastele) motivatsiooni teha misjonitööd Venemaa soome-ugri keeli kõnelevate rahvaste seas. Kirikuorganisatsioonid kurdavad, et raske on leida töötegijaid, eriti neid, kes tahaksid aastaid elada kodust kaugel (Väliaho 2004; HA 2008 (3): 18). Teiselt poolt on misjoneeritavatel suurem motivatsioon kuulata oma läänepoolseid "sugulasi".

Sugulustunde ärakasutamist ja sellega tekkiva suhte eripära olulisust väljendab ka Soome luteri pastor Jukka Repo, kes on aastaid elanud Venemaal ning Eestis. Ta kirjutab:

Hõimurahva esindaja tähendab minu jaoks keele- ja veresugulast. Soomlasena on mu suhe naabritega alati veidi keeruline. On suur vahe, kuidas suhtun rootslastesse ja venelastesse, ning kuidas suhtun oma sugulastesse eestlastesse. [...] olen saanud suhelda nii mordvalaste, eestlaste kui ka teiste sugulasrahvastega. Olen kogenud, et mind kuulatakse just sellepärast, et mind tuntakse kui sugulast - kadunud kauget sugulast, kes on tagasi tulnud. [...] Tihti ei kuula me oma rahva esindajaid nii hoolega kui kedagi kaugemalt tulnut, kes on samas nii lähedane nagu seda saab olla üks kadunud ja taasleitud sugulane. Siin on üks põhjus, miks hõimurahvaste misjoniprojekt ennast õigustab. (HA 2011 (6): 5)

Misjonäride esituses võetakse eestlasi ja soomlasi vastu kui pikka aega kadunud sugulasi. Siit leiab paralleeli kümne kadunud Iisraeli hõimu müüdist ehk aegade jooksul laiali pillutatud rahvastest, nende otsimisest ja taasühinemise ootusest (vt Ben-Dor Benite 2009). Nagu Repo märgib, pakub selline identifikatsioon „silla“, mida ära kasutada. Viitega Pauluse kõnele „tundmatust jumalast" Ateenas, mille kaudu tutvustab ta kreeklastele ainujumalat, esitab Repo tsitaadi apostel Pauluselt: „Ma olen saanud juutidele juudiks, et võita juute [...] Ma olen kõigile saanud kõigeks, et igal juhul mõned päästa“ (1 Kr 9: 20-22). Repo tõdeb: „Meilgi on võimalus ütelda: oleme saanud ugri-mugridele ugri-mugrideks, et võita võimalikult paljud Kristusele“ (HA 2011 (6): 5). Siin on esitatud üks keskne teoloogiline põhjendus, miks kasutada iga võimalust leida ühist identiteeti misjoneeritavatega: keelepõhine sugulus peab saama kristlikuks suguluseks, kus hõimuvennad ja -õed on ühtlasi ka usuvennad ja -õed. Seega ei ole hõimusidemete tugevdamine eesmärk iseenesest, vaid on vahend millegi olulisema saavutamiseks. Selles osas erinetakse nendest 
sekulaarsetest hõimuliikumise vormidest, mis seavad soomeugrilaseks olemise ja üksteise toetamise eesmärgiks iseenesest.

Nagu juba ülal mainitud, on Venemaa soomeugrilaste jaoks suguluse tuvastamine oluline - vähemalt paljudele. Väljaspool Venemaad elavate soomeurgilaste tähelepanu pakub tunnustust ja sõnalised identifitseerimised („oleme sugulased“) loovad emotsionaalse sideme. Samas on raske öelda, kui levinud see tunne on. Kindel on see, et see kerkib siin-seal esile, ilmselt rohkem läänemeresoomlaste juures ja Volga-aladel ning kasinamalt põhjarahvaste juures, kelle jaoks hõimuliikumine on vähem tuntud ja soome-ugri identiteet pigem nõrk.

Lisaks sugulusele on oluline ka vähemuste diskursus. Nelsoni väitel saab üks väikerahvas teist tunnustamata ja stigmatiseeritud väikerahvast paremini aidata. Suurte teisekeeleliste rahvaste (eriti venelaste, aga ka tatarlaste ja teiste) keskel elades on see oluline. Keelesuguluse tuvastamine aitab toime tulla identiteediprobleemidega, nagu Nelson kirjutab:

Hiljutisel reisil mari rahva juurde, kes elab viissada miili Moskvast ida pool, olin tunnistajaks sellele, kuidas noor naine nuttis nelipühi osadusgrupis, sest "keegi ei hooli meist, maridest. Keegi isegi ei tea, et me oleme olemas. Me sureme välja ja keegi ei hooli." Mul oli võimalus selgitada ses osadusgrupis, et isegi kui keegi ei ole kuulnud maridest, siis eestlased teavad neid ja hoolivad neist. Ma tegin ses osadusgrupis midagi õige lihtsat. Palusin maridel loetleda oma keeles kümneni. Kui nad ütlesid "ik“, ütlesin ma eesti keeles „üks", 2 - "kok", ütlesin "kaks", 3 - "kum", ütlesin "kolm", 4 - "nel“ ja ma ütlesin "neli“ ja nõnda edasi kümneni. Keelte vahelised sarnasused edastavad valju ja tugeva sõnumi: "Me ei ole üksi." Me usume, et Jumal on andnud Eestile erilise niši misjonitöös - kümne tuhande aasta jooksul kujunenud niši-, mis avab uksi väikestele etnilistele gruppidele, kes on ülejäänud maailmale tundmatud. Eesti kristlased, olles isegi väikese etnilise grupi liikmed, saabuvad mõistmise, sümpaatia ja armastusega ja näitavad oma kaugetele nõbudele, et nad on tegelikult väärtuslik Jumala looming. (Nelson 2009; vt ka HA 2009 (4): 2)

Ilmselt on nii mõnigi eestlane ja soomlane, kes on rännanud Venemaa soomeugrilaste seas, kogenud seda, kui mõni kohalik väljendab häbitunnet oma etnilise päritolu, vene keele kehva oskuse või muu sarnase pärast. Eluaegseks haavumiseks piisab sageli vaid ühekordsest solvangust stiilis „loll nagu vepslane“ (Romanova 2007: 10; vt ka HA 2006 (1): 5; 2008 (3): 9; 2010 (5): 17). Kristlikust vaatepunktist on stigmatiseeritus aga võimalus konversiooniks ja uue identiteedi loomiseks (mis on sageli vähemuse identiteet, mis võitleb samuti häbenemisega). See emotsionaalne suguluseretoorika pakub seega tõhusa motivatsiooni misjonäridele. Nimelt saavad nad esitada oma tegevust kui armastuse, hoole ja abistamissoovi realiseerumist. Siin on kokkupuutepunkt teiste soome-ugri liikumiste toimimisloogikaga: see on üks versioon abistamise diskursusest, mis on soome-ugri liikumises laiemalt levinud, kuid misjonäride eesmärk on eriomaselt kristlikust loogikast tulenev, kus keel ja kultuur on üksnes maised aspektid, mis tuleb allutada religioossetele eesmärkidele. ${ }^{7}$

[7] Mark Nelson kirjutab, et teadlaste eesmärk teha uurimistööd hõimurahvaste keele ja kultuuri säilitamiseks ei ole piisav: „Need rahvad on kurnatud alkoholismist, meeleheitest, suitsiididest ja kultuurilisest marginaliseeritusest. Milline on meie vastus sellele? Me ei või rahulduda pelgalt teadusliku töö viljelemisega soomeugrilaste keele ja kultuuri säilitamise 
Eesti ja Soome misjonis leidub vahel ka paternalistlikku suhtumist, kui esitatakse end „vanema venna“ positsioonilt, kellel on pakkuda eeskuju „väiksematele“ rahvastele. Nagu Rauli Lehtonen ühes intervjuus märgib, on suure venna positsioon kogenuma ja targema oma:

Eestlaste minevik on paljuski sarnane teiste rahvastega, kes on Nõukogude Liidus elanud. Ehk just sellepärast on eestlastel kergem ennast samastada nende probleemidega. [...] Eestlastel on võtmepositsioon. Eestlased on meiega sageli käinud Udmurtias, Mordvas ja Marimaal. Kohe on näha, et eestlasi võetakse vastu nagu sugulasi, nagu suuri vendi. Kui teie Eestist ei kasuta seda võimalust, siis kes seda võiks teha? Ma kardan, et neid inimesi ja rahvaid pole üldse olemas, kes võiksid teha seda tööd, mis on eestlastele ülesandeks antud. ${ }^{8}$

Eriti välismaa päritolu kristlased omistavad eestlastele erilist rolli ühelt poolt tänu nende positiivsele kuvandile Venemaa soomeugrilaste seas ja teiselt poolt ühisele nõukogude kogemusele, mis muuhulgas tähendab ka paremat vene keele oskust (mis eristab näitaks eestlasi soomlastest). Eestlastegi puhul on siin omad piirid, kuna Venemaa avalikkuses kuuluvad eestlased pigem „vaenlaste“ hulka (vt lähemalt Vallikivi 2018).

\section{Venemaa soomeugrilased ja protestantism}

Protestantlus on pikka aega olnud Venemaa soomeugrilaste seas täiesti tundmatu kristluse vorm. See-eest vene õigeusk on kõikjal mingil määral juurdunud: alates keskajast ollakse sellega kokku puutunud - kes varem, kes hiljem. Kui pilti oluliselt lihtsustada, siis võiks siinkohal rääkida tinglikult kolmest grupist. Enamiku jaoks pakub õigeusk domineerivat usulist identiteeti (setod, vadjalased, isurid, karjalased, vepslased, ersad, mokšad, mäemarid, komid, Koola saamid). Samas esineb nende usundilises maailmas ja kombestikus hulganisti komponente, mida kirjanduses nimetatakse „eelkristlikeks" ${ }^{9}$ Teise grupi jaoks on õigeusk varieeruva tähtsusega, kuna võistleb kohaliku religiooniga, mis on põhiolemuselt animistlik, küll aegade jooksul tugevalt naabruses levinud monoteistlikest religioonidest mõjutatud, aga ühtlasi siin-seal säilinud jätkutraditsioonina (niidumarid, udmurdid). ${ }^{10}$

nimel. Säilitamine on esimene hädavajalik samm, kuid meie eesmärk peab sisaldama ka praktilisi samme kultuuri ja ühiskonna tugevdamiseks, et võimaldada neil ületada tõkkeid, mis ähvardavad neid hävitada." (HA 2007 (2): 24) Selles, nagu teisteski analoogsetes kommentaarides on peidus veendumus, et kultuuri ja ühiskonna tugevdamine ei saa aset leida ilma konversioonita kristlusse.

[8] http://kuulutaja.net/2013/august2013.htm, vaadatud 30.11.2017. Kristlikku lehte Kuulutaja annavad välja baptistid.

[9] „Eelkristlik“ on problemaatiline mõiste, kuna enamiku Venemaa soome-ugri keeli kõnelevate rahvaste puhul ei saa rääkida kristluse-eelse usundi „säilimisest“, vaid aastasadade pikkusest bricolage' ist, milles on nii arhailist kui innovaatilist ja laenulist. Kirjanduses (k.a misjonialases) kutsutakse neid vahel „kaksikusu“ (двоеверие) praktiseerijateks. See on aga pigem „modernne akadeemiline konstrukt“, nagu märgib Rock (2007), mis on mõjutatud kristliku kiriku perspektiivist.

[10] Siingi on palju erinevaid variatsioone. On kohti, kus õigeusu esemed ja rituaalid mängivad keskset rolli (nt õigeusu kiriku lähedal asuvates külades), samas kui teisal puudu- 
Kolmanda rühma jaoks on domineeriv animistlik ontoloogia, millel on ühtlasi šamanistlik tagapõhi, ning õigeusk on üksnes võimalik usundilise identiteedi osis (põhjarahvad ${ }^{11}$ ). Olgugi et erineval määral ja viisil, on õigeusk mingil määral põimunud läbi suurema osa soomeugrilaste religioossest maailmast. Viimasel sajal aastal on lisandunud ateistlikke ja viimastel kümnenditel neopaganlikke ja uue vaimsuse praktikaid, mis on levinud kogu postsovetlikul Venemaal (Lindquist 2006; Aitamurto 2016). Samas tuleb rõhutada, et ühe „rahva“ sees on palju erinevaid usundilisi käitumisi ja suhtumisi.

Praegu on Venemaa soomeugrilastest protestantide osakaal arvuliselt teadmata. Kindel on see, et see on väga väike. ${ }^{12}$ Enamiku soome-ugri rahvaste seas on ilmselt tegemist gruppidega, kuhu kuulub mõnest sajast kuni mõne tuhande inimeseni. Samas on sellel kohalikule ühiskonnale piirkonniti ja rahvati erinev mõju. Näiteks võiks oletada, et nii mõnegi põhjarahva seas on suhtelisel skaalal protestantide osakaal suurem kui Volga ala soomeugrilastel. ${ }^{13}$

Venemaa soomeugrilaste seas on ainsaks protestantlikuks rahvaks Ingerimaa soomlased. ${ }^{14}$ Koos soomlaste ja eestlastega mängivad nemad hõimumisjonis keskset rolli. Ingerisoomlased on soomeugrilastele suunatud protestantlikus misjonis erilisel kohal mitmel põhjusel. Esiteks on see ainuke soome-ugri keelt kõnelev etniline grupp Venemaal, kellel on ajalooliselt välja kujunenud tugev luterlusega seotud etniline identiteet (vt Raudalainen 2014). Teiseks on ingerisoomlaste sunnitud hajaasustus misjonitöö läbiviimist soodustav asjaolu. Nimelt pakuvad nõukogude ajal üle terve impeeriumi laialipillatud rahvakillu esindajad vajalikku suhtevõrgustikku (vt nt Väliaho 2004: 97, 103). Pealegi on Ingerimaa soomlastel tihedad sidemed ingerisoomlastega Eestis ja eriti Soomes, kus on 1990. aastal alanud „tagasipöördumise“ tõttu Ingeri Evangeelsel Luterlikul Kirikul (lüh Ingeri Kirik) suur arv toetajaid. Kolmandaks on Ingeri Kirikul oma registreeritud nn rahvuskirik, mida

vad need pea täielikult (nt udmurdi ja mari külades tatari ja baškiiri enamusega aladel).

[11] Läänepoolsed neenetsid ja mõned handi grupid on õigeusust mõnevõrra tugevamalt mõjutatud (eriti kombestikus), seevastu nganassaanidel ja idapoolsetel neenetsitel on sellega olnud vähem kokkupuuteid.

[12] Näiteks Mark Nelsoni (teadmata allikatele rajaneval) hinnangul varieerub protestantide osakaal 0,02 protsendist mordvalaste seas kuni 0,2 protsendini udmurtide seas, samas kui venelaste seas on see 1,5 protsenti (2009; vt ka https://joshuaproject.net/, vaadatud 30.11.2017).

[13] Oma välitöömaterjalide põhjal oskan öelda, et neenetsi tundraelanikkonnast on evangeelseid kristlasi (baptistid, nelipühilased) mitusada, kes kõik on pöördunud viimasel paaril aastakümnel. Hõimurahvaste Aja veergudel täheldatakse samuti hantide arvukat pöördumist ja räägitakse paarisajast konvertiidist. Eestlased käivad hantide ja neenetsite juures misjoniretkedel väikeste gruppidena; aktiivseimad on metodistid Andrus Kask (handid) ja Signe Liivak (neenetsid ja handid) (vt HA 2010(5): 4-6; 18-19; 2011 (6): 8-9; 2012 (7): 16-17; 2013 (9): 7-9; 18-19; 2013 (10): 5-7; 2014 (11): 16; 2014 (12): 6-8; 2014 (13): 14-15; 2015 (14): 6-8; 2016 (15): 6-7; vt ka Wiget, Balalaeva 2007). Ajakirja Hõimurahvaste Aeg veergudel püüavad reisikirjad põhjarahvaste juurde ohtrate fotodega lugejaskonna tähelepanu. Eestlaste roll põhjarahvaste konversioonis on siiski suhteliselt tagasihoidlik ja ka ilmselt vähem pealetükkiv võrreldes vene ja ukraina protestantide jõulise misjoniga, mida olen oma välitöödel jälginud.

[14] Kui kõrvale jätta teised Venemaal elavad soomlased ja eestlased, kes on samuti luterlased. 
on ka Vene riik tunnustanud ja mille praostkonnad ulatuvad Narva jõest Baikali järveni. Ingeri Kiriku ametlik registreerimine riigivõimu poolt annab olulisi eeliseid uute koguduste rajamisel.

Nõukogude ajal oli Ingerimaa soomlaste kirikuelus tähtis roll just eestlastest kirikuõpetajatel. Teise maailmasõja järel, kui eestlased leidsid end vastu tahtmist samast riigist kui ingerisoomlasedki, hakkasid eesti luterlased tihedalt suhtlema ingerisoomlastega, nii Eestis kui ka ida pool Narva jõge. 1959. aastast ristis ja leeritas eesti pastor Elmar Kull ingerisoomlasi. Tema ja terve rida teisi eesti pastoreid käisid Ingerimaal ja Karjalas teenimas. Võimud lubasid rajada aastal 1970 koguduse Karjala ANSV pealinnas Petroskois ja aastal 1977 Peterburi eeslinnas Puškinis (Raudalainen 2014: 421-423). Mõlemad kogudused kuulusid ametlikult Eesti Evangeelse Luterliku Kiriku koosseisu. Eestlased jutlustasid seal soome keeles või ka tõlgi vahendusel. 1992. aastal moodustati eraldi Ingeri Evangeelne Luterlik Kirik. Ingeri Kiriku taastajaks (herättäjä 'ärataja') peetakse ingerisoomlast Arvo Survot. ${ }^{15}$

Ingeri Kirikul oli 2011. aasta seisuga 80 kogudust ja umbes 15000 liiget (HA 2011 (6): 18). Kui vaadata Ingeri Kirikut tervikuna, siis on tegemist „,venelaste kirikuga“. Piiskop Aarre Kuukauppi sõnul on vaid umbes 40\% kiriku liikmeskonnast luterlike juurtega soomlased, eestlased ja sakslased (Soom 2016: 4). Ülejäänud on venelased ja teised mittesoomeugrilased, kes on hiljuti liitunud misjonitöö tulemusel. Nii on enamik pastoreid (üle 80\%) mitteluterlike juurtega (üle poole kõigist pastoritest on ukrainlased), kes soome keelt ei oska (Soom 2016: 4). Seetõttu on Ingeri Kirik täna ülekaalukalt venekeelne kirik.

\section{Idapoolne misjon}

Idapoolsete soomeugrilaste seas saab hõimumisjon alguse just Ingeri Kirikust ja Arvo Survo tegevusest. Esmalt aga tuleb meenutada seda sotsiaalset ja poliitilist konteksti, milles esimesed protestantlikud kogudused idapoolsete soomeugrilaste seas rajati. 1989. aastast algab aktiivse rahvusliku liikumise aeg. Suuremad soome-ugri rahvad Venemaal nõudsid riigilt oma keele ja kultuuri kaitsmist ning toetamist. Rahvuslikud liikumised olid erineva aktiivsusega (tugevaim oli see Marimaal) ja igal pool sisemiselt lõhenenud. Olgugi et religiooni olulisus oli eri rahvaste liikumistes mõnevõrra erinev, tõusetus rahvuslike liikumiste sees küsimus, kas religioosses plaanis taastada-luua midagi „oma“ või võtta üle mingi kristluse vorm ja püüda seda kohandada vastavalt oma rahvuslikele joontele ja eesmärkidele.

Pea kõikjal Volga alal leidus haritlasi, kes otsisid uues rahvuslikus identiteediloomes kohta nn eelkristlikule ehk „oma usule ${ }^{\prime \prime}{ }^{16}$ Kõige olulisem oli see rahvus-

[15] Arvo Survo on sündinud aastal 1954. Ta õppis 1980. aastatel Usuteaduste Instituudis Tallinnas ja 1987. aastal sai temast Eesti Evangeelse Luterliku Kiriku pastor Ingerimaal. Ta on ka muusik, luuletaja ja pärimuse koguja. Alates 1999. aastast elab Soomes ja on Soome Luterliku Evangeeliumiühenduse misjonär Venemaal. Abielus on ta eestlanna Kristaga (Tervonen 2007; HA 2017 (17): 3-4).

[16] Vene keeles nimetatakse seda sõnaga язычество (paganlus). Paganluse sõna kasutavad nii kristlikud kirikud kui ka teadlased. Reeglina ei meeldi see nimetus soomeugrilastele ja pigem juurutatakse oma väljendeid. Näiteks udmurtidel on üks variant удмурт оскон (ud- 
likus liikumises maridele, vähemal määral udmurtidele, kelle jaoks oli katkestus nõukogude-eelse olukorraga mõnevõrra ulatuslikum. Mari ja udmurdi külades eriti idadiasporaas - on oma usku alles hoitud jätkuva traditsioonina ning kus see on katkenud, on toimunud taaselustamine kohalikust initsiatiivist lähtuvalt (eriti ohvripalvused). Mari (ja vähem udmurdi) linnaharitlaste seas on olnud laialdane püüd süsteemselt rekonstrueerida varasemat usundilist traditsiooni ning luua organisatsioone selle legitimeerimiseks: kuivõrd leidus veel religioosseid spetsialiste, kes olid oma teadmised ja oskused pärinud esivanematelt, oli valik „mari usu“ kasuks igati loogiline (vt Alõbina 2017).

Vene õigeusuga enam seotud ersade, mokšade, sürja- ja permikomide jaoks on valikud mõnevõrra teistsugused, kuna kogukondi siduvaid mittekristlikke rituaale ja mittekristlikku (või kristlusest vähemõjutatud) pärimust ja praktikat on alles vähe. Tundub, et nii leidub ka viimaste seas enam neid, kelle jaoks protestantlus (eriti luterlus) osutub atraktiivseks, sest „oma“ jõulist religioosset traditsiooni pole. Võrreldes vene õigeusuga, mille nimeski on vene komponent ja mille väline külg on rangelt reglementeeritud, on luterlikel misjonäridel lihtsam esitada oma kristluse vormi rahvuslikuna: vormikeelt on võimalik kohandada sellega, mida peetakse rahvuslikuks (rahvarõivad, laulud, dekoratsioonid jne). Rahvuslaste ja ka paljude "tavainimeste" vaatepunktist on ligitõmbav just see, et protestandid saabuvad sõnumiga, et oma keelt tuleb säilitada, samas kui õigeusu vaimulike seast kostub vaenulikke hääli omakeelse kirikuelu vastu (seda eriti 1990. aastatel). Pea kõikjal, kus protestandid on püüdnud kanda kinnitada, on sellele VÕK, vene rahvuslikud organisatsioonid, aga vahel ka kohalikud võimud ning "traditsionalistid “17 vastu astunud.

Vaatlen järgnevalt nelja suuremaarvulise soome-ugri rahva suhet praeguste kristlike kirikute ja misjonitega. Olulisel kohal on siin luterlased. Ingeri Kiriku „ärataja“ Arvo Survo algatas idapoolse luterliku „hõimumisjoni“ - ajal, mil Ingeri praostkond kuulus formaalselt veel Eesti Evangeelse Luterliku Kiriku (EELK) alluvusse (Väliaho 2004: 57; Tervonen 2007: 272-273). Nüüdseks on sel viisil tekkinud Ingeri Kiriku Uurali praostkond, kuhu kuuluvad soome-ugri rahvastest mordvalased, marid, udmurdid ja komid. Koguduste arv ei ole siiski suur, arvestades praostkonna suurust. ${ }^{18}$

murdi usk) või maridel марий йӱла (mari komme). Need tähistajad on erineva ajalooga ja kujunenud välja võrdluses kristluse või islami tähistajatega ning käesoleval ajalgi on need mõisted muutumises (vt Alõbina 2017: 12; Dušenkova 2013: 83).

[17] Tähistan sõnaga „,traditsionalist“" põlisusundi kaitsjaid, kes püüavad aktiivselt võidelda oma usundi koha eest religioossel maastikul. Nende hulka ei loe ma inimesi, kes lihtsalt järgivad väljakujunenud põlisusundilisi kombeid, aga ei tegele selle ideologiseerimisega. Muidugi pole piir kahe grupi vahel selge, vaid suuresti tinglik, kuna inimesed võivad võtta situatiivselt erinevaid rolle ja suhtumisi.

[18] Ingeri Kirikul on Mordvas kaks kogudust Saranskis, üks kogudus mokša kogukonnaga Kovõlkino väikelinnas. Marimaal on Joškar-Ola kogudus ning Ljupersola kogudus, abikirikukogudused on veel Zvenigovo ja Paranga väikelinnas. Komimaal on kogudus Sõktõvkaris ja Troitsko-Petšorskis. Udmurdimaal on kogudus Gurez-Pudga külas ning Baškortostanis Neftekamski ja Birski linnas. Lisaks on terve rida nn kuulutuspunkte ehk mitteformaalseid kodugruppe, millel on potentsiaal kujuneda koguduseks. Peale soome-ugri alade on Uurali 


\section{Ersad ja mokšad}

Survo huvi soome-ugri rahvaste ja keelte vastu tekkis 1970ndatel ersast tädimehe vahendusel, kelle käest õppis ta kuigipalju ersa keelt. 1989. aastal sattus ta suhtlema noorte mordvalastega, kelles ärgitas ta huvi emakeelse kiriku loomise vastu (Tervonen 2007; HA 2010 (5): 10). Survo külastas ersa kunstniku Andrei Aljoškini ja tema venna Aleksei kutsel korduvalt Mordvamaad, kus ta aitas esimesi mordva vaimulikke koolitada ja luua Saranskis luteri kogudus, mis hiljem jaguneb kaheks - mokšade ja ersade koguduseks. ${ }^{19}$ Venekeelsete inimeste liitudes muutuvad need aga üha venekeelsemaks. Praeguseks on need sisuliselt segakogudused, kus vene keel domineerib ja on näiteks tähtsaima pühapäevase jumalateenistuse keel, kusjuures jutlused on venekeelsed ja vaid osa liturgilisest poolest on kohalikes keeltes (Pienoisevankeliumi 2015: 19; isiklik teade Anna Mišinalt). Aleksei Aljoškin tunnistab, et jumalateenistuse küsimus on „keeruline“, kuna koguduses on nii ersad, mokšad kui venelased (Filatov 2017a: 300). Samuti toimetavad välismisjonärid reeglina vene keeles. Nii näiteks töötas 1999-2001 Saranskis eestlanna Liliann Grünvald (Keskinen), kes oli seal EELK ja Soome Rahvamisjoni misjonärina „lasteja noortetöö" peal, mida ta tegi samuti vene keeles.

Nagu udmurdi uurija Konstantin Zamjatin märgib, oli 1990. aastate algul ersade ja mokšade rahvuslik liikumine Mastorava sisemiselt lõhenenud demokraatide ja kommunistide, aga ka õigeusklike ja protestantide vahel (Zamyatin 2013: 145). Siia võiks lisada ka „uuspaganad“, kes näevad end traditsioonilise religiooni rekonstrueerijatena. Religioonisotsioloog Filatov kirjutab, et luterluse enda jaoks avastanud ersa kunstniku Andrei Aljoškini jaoks etendas õigeusu kirik „venestavat jõu$\mathrm{du}^{\prime \prime}$ ja selle asemel püüdsid ersa aktivistid rajada "mordva rahvuslikku kristlust“ luterluse juurutamise abil, lisades rahvalikke elemente nagu näiteks itkemine, rahvalaulud ja -rõivad (Filatov 2017a: 296). Luterliku kiriku aktivistid sõitsid Mordvamaal ringi koos laialt tuntud folkloristidest koosneva ansambliga Toorama (eesotsas Vladimir Romaškin, 1951-2002) ning esinesid laulude vahel jutlusega. Tänu sellele said luterlased Mordva vabariigis üsna tuntuks (Bourdeaux, Filatov 2005: 233; vt ka Tervonen 2007: 277). Samas märgib jällegi Bogatova, et Romaškin oli just üks neist aktivistidest, kes püüdis koos luuletaja Mariz Kemali ja teiste traditsionalistidega taaselustada ohvripalvuseid, mis meelitasid 1990. aastate lõpul kokku tuhandeid inimesi (Bogatova 2015: 64). ${ }^{20}$

Kujunenud olukorras püüdis VÕK kontrollida kohalikku religioosset maastikku. Nagu mujalgi (vt allpool) on tekkinud siin-seal probleemid luterlike koguduse hoonete rajamisega, kuna VÕK on suutnud mõjutada kohalikke võime. Näiteks

praostkonnal ka nn mittesoome-ugri kogudused Tšuvaššia pealinnas Tšeboksarõs ja Tatarstani pealinnas Kaasanis (http://elci.ru/uralskoe-probstvo/, vaadatud 30.11.2017).

[19] Mokša-ersa koguduse (asutatud 1991) eesotsas oli pikka aega mokša Mikiž Mišin (19472018), Velmema kogudust (asutatud 1995) juhib ersa Aleksei Aljoškin (snd 1968).

[20] Üks osa haritlastest vastandas end igasugusele kristlusele ja püüdis luua ",taastatud“ ersa religiooni, mis aga omandas tugevaid uuspaganlikke jooni. Näiteks viidi 1991. aastal läbi avalikud ohvripalvused ozks (озКс), mida kanti üle televisioonis. Tollal sõideti palju ringi ka külades, et tutvustada (re)konstrueeritavat "paganausku“. Näiteks aastal 1998 kogunes palvustele Tašto Kšumantsjas mitu tuhat inimest (Bourdeaux, Filatov 2006: 152-153). 
keelati Saranskis luteri kogudusel rajada kirikut kesklinnas krundile, kuhu võimud andsid esialgu ehitusloa. Hiljem kuulutati see koht ehituseks mittekõlbulikuks, mille järel kerkis aga peagi samale kohale hoopis VÕKi kirikuhoone (HA 2010 (5): 11). Luterlastel tuli ehitada kirik teise kohta. Saranski õigeusu piiskop Varsonofi (ametis 1994-2014) süüdistas 1995. aastal ajaleheartiklis kohalikke luterlasi, viidates neile kui "Soome spioonidele“, et nood tegelevad mordva rahva "luteraniseerimise“ ja lõhestamisega, ,eemaldades seda vene rahvast“ (Bourdeaux, Filatov 2005: 233; Filatov 2017a: 298). Ersa ja mokša rahvuslaste mure keelte säilimise pärast oli piiskopi sõnul sekundaarne probleem. Nii kirjutab ta: „,... tuleb säilitada mordva keel [sic!], aga mitte iga hinna eest, mitte rahva konfessionaalse lõhestamise hinnaga" (tsiteeritud Bourdeaux, Filatov 2005: 226). Filatovi sõnul ei tunnistanud Varsonofi ersade ja mokšade rahvuslust ning pidas tõeliste väärtuste kujundamist võimalikuks üksnes venekeelse vene õigeusu raames (Filatov 2017a: 297). Siiski lõi Varsonofi juhitud Saranski ja Mordva piiskopkond tõlkekomisjoni, aga tõlketöid kohalikesse keeltesse sisuliselt ei tehtud (Filatov 2017a: 298). Filatovi hinnangul oli domineeriv suhtumine, et tõlked on ebavajalikud ning pealegi tsaariaegsed ning lääne tõlked jäävad rahvale arusaamatuteks, kuna need on kirjanduslikus keeles (vt lähemalt tõlkimisest Vallikivi 2018).

Viimastel aastatel on aga VÕK Mordvamaal hakanud oluliselt enam tähelepanu pöörama ersadele ja mokšadele. 2011. aastal loodi eraldi piiskopkonnad mokšade enamusega alal (keskusega Krasnoslobod) ja ersade enamusega alal (Ardatov). Kummagi ala juhiks on valitud vastavalt mokša ja ersa piiskop. Kahest aktiivsem on ersa piiskop Veniamin, keda Filatov iseloomustab kui ersa keele ja kultuuri eest võitlejat, aga samas ka kui „tulihingelist“ misjonäri, kes kasutab ersa keelt ersa kogudustes ja osaliselt isegi vene-ersa segakogudustes. Veniamini hinnangul on ersad „religioossemad“ kui venelased, samas aga hoidvat nad kinni vanadest tavadest: näiteks ühes külas palvetatavat pärast jumalateenistust kolme püha tamme all (Filatov 2017a: 300-301). Ühelt poolt võib taolisi süüdistusi pidada omaette žanriks, mida VÕK on aastasadu viljelenud. Teiselt poolt annab see tunnistust, et esivanemate kombel oma vahetu keskkonnaga suhestumine ei ole mordvalaste seas kuhugi kadunud.

\section{Marid}

Nagu nägime Mordva puhul, kujunevad just isiklikud kontaktid ühelt poolt haritlaste-loovisikute ja teiselt poolt usukuulutajate vahel protestantide misjonitöös keskseks. Nõnda ka Marimaal. Siiski oli huvi luterluse vastu seal visam tekkima kui Mordvas. Marimaa luterlik misjon sai tõuke mari ajalooprofessori Valeri Patruševi pöördumisest luterlusse. Ta kutsuti 1991. aastal loenguid lugema Helsingi ülikooli, kus kohtus teda kuulama tulnud luterlase Juha Väliahoga. Järgmisel aastal Soomet külastades elas ta Juha ja tema eestlasest abikaasa Anu Väliaho juures. Sel korral lasi ta end Hyvinkää luterlikus kirikus ristida ja leeritada, saades nõnda esimeseks Ingeri Kiriku liikmeks Marimaal. Patrušev pani ette, et Väliahod võiksid JoškarOlasse misjonitööd tegema tulla. 1993. aastal rajati esimene mari luterlik kogudus 
ja 1994. aastal õnnistas Ingeri Kiriku piiskop Juha Väliaho pastoriks (Väliaho 2004: 73-77; HA 2013 (10): 8). Juhast sai Uurali praostkonna praost ning Anust EELK poolt lähetatud misjonär Venemaal. Väliahodest kujunesid kahekümne aasta jooksul (1993-2012) olulisimad luterlikud misjonärid ja koguduste rajajad Volga ala soomeugrilaste seas. Kui alguses olid Joškar-Ola luterlikus kogudus vaid marid, siis ajapikku sai sellest mari-vene kogudus. ${ }^{21}$

Maride seas ei tekkinud rahvusliku liikumise ajal protestantluse vastu sedavõrd suurt huvi nagu Mordvas. ${ }^{22}$ Nii ei suutnud Väliahod aastaid leida endale ühtegi marikeelset haritlast, kes oleks valmis hakkama vaimulikuks ja aitama neid marilaste pööramisel (Väliaho 2004: 148). Olgugi et nende Marimaale kutsuja Patrušev ja ka keeleteadlane Valeri Veršinin panustasid kristlike tekstide tõlkimisse, ei saanud nendest põhikohaga pastoreid või misjonäre. ${ }^{23}$ Mari keele kasutamise koha pealt tuli läbimurre 1999. aastal, mil mari ajakirjanik Gennadi Aleksejev hakkas luteri kiriku vastu huvi tundma. Ta kirjutas ajalehelugu luterlastest, kuid lehed keeldusid lugu avaldamast. Nagu Väliaho märgib, oli põhjus selles, et erinevalt vene õigeusust, mari „loodususust“ ja islamist ei ole luterlus Mari-Elis ametlik religioon (Väliaho 2004: 148). Aleksejevist sai diakon Joškar-Ola luterlikus koguduses.

Joškar-Ola luterlik kogudus on vene- ja marikeelne. Keele valdamine, erinevate murrete ja registrite kasutamine mõjutavad otseselt seda, kas ja kes kirikus käib. Nii märgib Piret Riim, toetudes Eestis elava mari muusiku Inga Pogonina sõnadele, et Aleksejevi mari keel oli kirjakeelne ja rikkalik, meelitades ligi haritlasi (HA 2013 (10): 8). Ta tõlkis usutekste (nt Lutheri „Väike katekismus“ jmt) ja hümne, osales koguduse ajakirja Sorta (aastast 2002) väljaandmisel. 2012. aastal Aleksejev suri ning Pogonina sõnul tema asendaja „ei valda mari kirjakeelt nii meisterlikult kui tema eelkäija, vaid kasutab kodupaiga dialekti“ (HA 2013 (10): 8). Peagi kadusid JoškarOla „mari-vene“ koguduses laupäevased marikeelsed teenistused ülepea ning alles jäid vaid venekeelsed pühapäevased teenistused.

Marimaa luterlaste suhted VÕKiga on olnud pikka aega keerulised. Sealne piiskop (praegune metropoliit) Ioann oli 1990. aastatel meelestatud üsna vaenulikult nii protestantide kui ka mari „loodususuliste“ suhtes. Aga kuna Mari-Eli juhid ei soovinud konflikte traditsionalistidega ja pigem toetasid nende ettevõtmisi, oli ka VÕKi esindajatel raskem teha „paganate“ aadressil valjuhäälset kriitikat (Filatov 2017b: 287). ${ }^{24}$ Nagu Mordvaski on ka Marimaal kinnisvara ja krundid see vald-

[21] 2013. aastal oli liikmete arv 130 (vt HA 2013 (10): 9). Filatovi andmeil on seal umbes sada leeritatud liiget ning „usklikke, kes tulevad jumalateenistusele, on mitu korda rohkem“ (2017b: 283).

[22] Tekivad üksikud baptisti ja nelipühi kogudused, kus lauldakse ja loetakse evangeeliumit emakeeles. Aga võrreldes ülejäänud Venemaaga on Filatovi hinnangul omakeelsete nelipühilaste edu seal üllatavalt tagasihoidlik (Filatov 2017b: 283). Nelipühi kiriku teke on seotud soomlaste tegevusega 1990. aastatel, kogudus loodi 2001 ja registreeriti ametlikult 2013 (https://vkfaces.com/vk/public/mari_hve, vaadatud 30.11.2017).

[23] Veršinin lasi end 2001. aastal ristida (Väliaho 2004: 150). Ta oli 1990. aastate algul aktiivne mari loodususu taastamise eestkõneleja rahvuslikult meelestatud organisatsioonis Kugeze Mlande (Prozes 2015: 29).

[24] Olles üks kolmest „vabariiklikust“ religioonist, on „mari traditsioonilise usu“ preester (kart) osalenud vabariigi juhtide inauguratsioonidel, samuti on registreeritud üheksa traditsionalistide „kogudust“ ning 600 hiit on kaitse alla võetud. 2014. aastast on koolipro- 
kond, kus protestandid saavad tunda kohalike võimude ja VÕKi, aga vahel lisaks ka põlisusundi praktiseerijate vastuseisu.

Joškar-Olast kolmekümne kilomeetri kaugusel Ljupersola (Šuarsola) külas rajati 2005. aastal umbes viiekümne inimesega luterlik kogudus. Nagu kirjeldab antropoloog Sonja Luehrmann (2012), kes on uurinud ateismi ja religiooni rolli Marimaal, tekkis külas koguduse rajamise käigus terav vastuolu. Ehituskrundi eraldamisele seisis ühel koosolekul teravalt vastu mari külavanem, kes väitis, et kiriku rajamisega on kaalul küla ja kohalike maride saatus. Külavanema sõnul suudeti inimesi värvata luteri kogudusse tänu riiete ja toidu jagamisele, sest ollakse vaesed. Samuti hoiatas ta, et "soomlased“ ei taha rajada kogudust „niisama“ ja neil on "halb eesmärk“. Koosolekul oli kohal ka kaks õigeusu preestrit. Külavanem tunnustas õigeusu kiriku rolli, kuid samas avaldas arvamust, et „paganlus“ peaks olema külas eelistatud usk. Luterlaste tegevus aga ähvardab „hävitada Venemaa alused“ ning sellesse usku pöördujad liituvad selle "halva eesmärgiga“, olles samas ka reeturid (Luehrmann 2012: 29-30). ${ }^{25}$ Luteri kogudus sai siiski loa ehitada koguduse hoone. Filatovi teatel on Ljupersola koguduses vaid marikeelne teenimine ning koolilapsed osalevad seal aktiivselt (2017b: 284). Külas elavate luterlaste seas on täheldada eri traditsioonide kokkusulatamist, näiteks „mari paasapühade“ ja suure neljapäeva tähistamist saunas läbiviidavate „paganlike“ rituaalidega (2017b: 284; vt ka Mišina 2016 idamaride sünkretistlikest praktikatest).

2000. aastatest alates on Filatovi sõnul VÕKi piiskop Ioann ja tema kaastöötajad oma seisukohti mõnevõrra mahendanud ning valinud mari vaimulikkonna koolitamise ja misjonitöö mari keeles, olles mõistnud, et protestantide põhjamine õigeusu levitamisel üksi edu ei too (2017b: 280-282). Viimastel aastatel on Marimaal mõned õigeusu kogudused, kus esitatakse liturgiat üksnes mari keeles. Samuti toimub misjon ikonostaasiga väljasõitudena „paganlikesse“ paikadesse, kus pühitsetakse maju, allikaid ja korraldatakse marikeelseid jumalateenistusi (2017b: 282). Erinevalt protestantidest kuulub õigeusklike tegevuskavasse ka paikade „pööramine“.

Idamaride juures Baškiirias on olukord mõnevõrra teistsugune, sest seal puudub tugev VÕK ning luterlased saavad vabamalt toimetada. Ilmselt on ka kohalikud võimud vähem aktiivsed, kuna tegemist on traditsioonilise islami alaga ning kristlaste sisemised heitlused lähevad neile vähem korda. Aastail 2005-2012 elasid Väliahod Birskis Baškortostani õigeusustamata idamaride juures, kus nad asutasid luterliku koguduse. ${ }^{26}$ Mari koreograaf ja rahvatantsuõpetaja Slava Abdullin oli esmaristitu ja aastast 2009 ka pastor (HA 2010 (5): 18). Lisaks temale on luterlasteks hakanud mõned kohalikud mari estraadimuusikud, kes on hästi tuntud kogukon-

grammis võimalik õpetada ainet „mari traditsiooniline religioon“ (Filatov 2017b: 288-289, vt ka Alõbina 2017).

[25] Filatovi hilisema teate järgi on külas „paganlik ühing oma palvemajaga. Paganatega pole samas mingeid kokkupõrkeid olnud - kart (preester) räägib, et kõigest hoolimata tulevad kõik traditsioonilise usu juurde. Vaenulikkust esineb üksnes VÕKi esindajate poolt" (2017b: 284).

[26] Idamaride seas on luterlaste arv „üle 200“, ning kogudusi tegutseb kolmes linnas ja seitsmes mari külas (HA 2007(2): 7; vt ka 2012(7): 3-5; 2012(8): 6, 18; 2015(13): 18; 2016(16): 17). Teise allika järgi on "70 ristitut Baškiiria paganausku maridest" (Toompuu 2009: 5) või üle 300, kellest on „enamus marid“ (Sadikov 2016: 20). 
nas ja kes teevad misjoneerimise eesmärgil tasuta kontserdituure kultuurimajade täissaalidele (HA 2010 (5): 14-15; 2011 (6): 6). Kirikuelu on külades marikeelne, Birskis aga vene- ja marikeelne (Kljašev 2013: 79; Pienoisevankeliumi 2015: 19). Samas tegid Väliahod misjonitööd vene keeles, kasutades vajadusel tõlke. Ses kandis on mittekristlikud traditsioonid olnud ajalooliselt tugevad, kuna õigeusu mõju on olnud tagasihoidlikum. Siin leiavad protestandid ka valjuhäälseid kriitikuid mari aktivistide seast, kes süüdistavad luterlasi mari kultuuri hävitamises. Idamaride seas kostub hääli „,soomlaste“ misjoni vastu, eriti „paganausu“ pappide seast. ${ }^{27}$ Tähelepanuväärne on see, et nii idamaride kui ka ülalmainitud Ljupersola juhtumi puhul kasutavad traditsionalistid Venemaal levinud protestante ja välismaalasi halvustavaid stampe, et kaitsta oma huve.

\section{Udmurdid}

Nagu maridegi puhul on ka udmurtide seas levinud mittekristlikud usundilised praktikad (siin-seal lõunapoolsetel Udmurdimaa udmurtidel ja aastasadade eest väljarännanud Kaama-taguste udmurtide järeltulijatel). Samas on õigeusk mõnevõrra tugevamalt juurdunud kui niidumaride seas. Protestantlike misjonite töö tulemuslikkus on pigem napp.

Udmurdimaal ei ole Ingeri Kiriku luterlikul misjonil linnaharitlaste seas erilist edu olnud. On suudetud rajada vaid üks kogudus, mis asub udmurdi külas GurezPudgas. Pastor on seal aga tatarlane, kes räägib koguduseliikmetega vene keeles, olgugi et tegemist on udmurdikeelse külaga ning koguduse liikmed räägivad omavahel udmurdi keeles (Pienoisevankeliumi 2015: 19). See-eest on Udmurdimaa suurimas protestantlikus liikumises, milleks on nelipühi kirik Filadelfia, märkimisväärne arv udmurdikeelseid liikmeid ja mõned kogudusedki. ${ }^{28}$

VÕKi roll udmurtide seas on viimastel aastakümnetel olnud vastuoluline. Umbes kümme protsenti Udmurdimaa õigeusu vaimulikkonnast (üle kolmekümne inimese) on udmurdid; neist ei valda kaugeltki mitte kõik udmurdi keelt. Kahes kirikus Iževskis ja ühes Tatarstanis kasutatakse udmurdikeelseid liturgiaid teenistustel ning mõnel pool jutlustatakse udmurdi keeles (Lunkin dateerimata). Olgugi et udmurdi keelt kasutatakse vähe, on see olnud vastukarva osale venemeelsest vaimulikkonnast. 1990. aastatel kujunesid pinged eriti suureks, kuna munkprees-

[27] Vaata nt Ilja Evanõn-Birski (2009) avaldusi.

[28] Udmurtide seas on ilmselt enim konvertiite just nelipühi Filadelfia (Филаделфия) organisatsioonis. Nelsoni teatel on Filadelfia nelipühilaste seas 50 udmurti, sh viis kodugruppi (HA 2009 (4): 6). Filatovi sõnul on Filadelfia 40 koguduse ja 60 pastoriga organisatsioonis veerand udmurdid; aastal 1998 peeti neljas koguduses udmurdikeelseid jumalateenistusi ning oli üks udmurdi pastor nimega Valeri Pikulev (Bourdeaux, Filatov 2005: 333; HA 2010 (5): 17). Aastal 2015 oli Filadelfial oma allüksus nimega „Udmurdi Kirik“ ning folklooriansambel Inkrez (Инкрезь), mis tegi misjonitööd udmurtide seas, sh Kaama-taguste udmurtide juures (Vorontsov, Tšernijenko 2015: 165). 
ter Antoni ${ }^{29}$ põletas kirikuõues Mihhail Atamanovi ${ }^{30}$ udmurdikeelseid pühakirjatõlkeid ning keeldus armulauda andmast neile, kes kasutasid tõlkeid ja mitte vene kirikutekste (Atamanov 1999: 67; Bourdeaux, Filatov 2005: 325; vt ka Lunkin dateerimata). Atamanov leidis endale väga hääleka vastase Antoni näol. Too väitis, et jumalasõna võib uurida vaid kreeka ja kirikuslaavi keeles ning mööndustega ka vene keeles: olgugi et vene keel on "moonutatud", on see slaavi keel. See-eest kohaliku keele kasutamine viib põrgusse ja „neid tõlkeid on väga vaja deemonitele inimeste hukutamiseks" (Atamanov 1999: 66). Udmurdi keele ja teiste väikerahvaste keelte kohta kirjutab Antoni:

Udmurdi keel - nagu kõik väikeste rahvaste keeled, millel viimase ajani puudus kirjakeel pole kaugeltki täielik ega suuda kanda õigeusu täit vaimset rikkust [...] Ei ole vaja end vaevata rahvusliku kultuuri ehitamisega, vaid on vaja kohe pöörduda kõrgema poole - omandada kalleim aare, milleks on kirikuslaavi keel, Uue Iisraeli, Püha Venemaa, Kolmanda Rooma vundament ja sellega ka kogu õigeusu rikkus. (tsiteeritud Atamanov 1999: 66)

Antoni agiteeris teisi vaimulikke udmurdikeelseid tekste põletama, mida siin-seal Udmurtias ka tehti. Kui mõni vaenulikult meelestatud vaimulik nägi mõnd Atamanovi tõlget, kästi see omanikul hävitada kui saatanlik tekst (Atamanov 1999: 67-68). Nii kirjeldab Atamanov veel juhtumit, kui Antoni keeldus vastu võtmast pihti ja andmast armulauda vene keelt mitteoskavale udmurdi memmele, kuna eeldas, et too on pihiks ettevalmistumisel kasutanud udmurdikeelset palveraamatut. Ühel teisel korral teatab Antoni pihiletulnuile, et vaid kirikuslaavi keel on Jumalale meelepärane ja üksnes selle kaudu toimub pääsemine (Atamanov 1999: 68-69). Selline ei ole siiski Moskva patriarhaadi pealiin ega ka mitte kõigi kohalike vaimulike seisukoht (Atamanov 1999: 61, 73-77, aga vt ka 107). Mõistetavalt on paljud udmurdikeelsed koguduseliikmed pahased. Udmurdid Svjato-Nikolskaja kirikust kirjutavad: „Juhul kui te keelate meil ülistada ja teenida Jumalat meie emakeeles, siis võib õigeusk kaotada suure osa usklikest ja paljud võivad siirduda paganausku ja sektidesse, mis on veelgi hullem“ (Atamanov 1999: 78). Nemadki kasutavad protestantluse ja kohaliku usundi taktikalist demoniseerimist.

[29] Ilmalik nimi on Aleksei Malõhh. Udmurdi kirjaniku ja teadlase Anatoli Uvarovi sõnul on tegemist päritolult udmurdiga, kes on venestunud (Atamanov 1999: 82).

[30] Mihhail Atamanov (snd 1945) on tuntud kui keeleteadlane ja piibli tõlkija udmurdi keelde. Kandidaaditöö kaitses ta onomastika alal 1978. aastal Tartu Ülikoolis Paul Ariste juhendamisel. Õigeusklik Ariste kinkis Atamanovile udmurdikeelse evangeeliumi uustrüki, mille oli välja andnud Piiblitõlke Instituut ja mis oli Eestisse toodud salaja (Atamanov 1999: 133). Atamanovist sai vaimulik 1989. aastal ning järgmised aastad tegeles ta peamiselt piibli tõlkimisega, jätkates samas ka keeleteaduslike uurimustega (vt Zagrebin, Išmuratov, Kirillova 2011: 3-4). Ta teeb aeg-ajalt udmurdikeelseid kristliku sisuga raadiosaateid (Atamanov 1999: 62, 86, 95, 149) ning kirjutab ajalehes Удмурт дунне rubriigis Оскон (Usk), kus avaldatakse vaid õigeusu vaimulike tekste ja kus tehakse aeg-ajalt udmurdi usundit halvustavaid avaldusi (isiklik teade Nikolai Anisimovilt). Ariste käe all õppis ka hilisem ersa piiblitõlkija Nina Aduškina (Laakso, Aduškina 2008: 120-121). 


\section{Sürjakomid}

Stalini ajal küüditati ja viidi vangilaagritesse Komimaale tuhandeid protestantlikke sakslasi, läänepoolseid soomeugrilasi ja teisi. Ellujäänutest ja vabanenutest ning ka sinna hiljem küüditatud protestantidest jäi osa elama Komimaale. Seal loodi oma luterlikke, mennoniitlikke, baptistlikke jt kodukirikuid. Samas olid jumalateenistused varjatud. Sakslaste seas olid need pealegi saksakeelsed ning komide seas misjonitööd ei tehtud (vt Koosa 2017: 28).

Komi protestantluses on kesksel kohal Komi Kirik (komi Коми вичко) (Filatov 2016: 383). Selle rajas 1960. aastatel Vassili Popov (1921-1991), kelle juures kodus käis regulaarselt umbes viisteist komi. Eesmärk oli rajada komi rahva jaoks omakeelne kristlik kirik: koos lauldi komi vaimulikke laule ja välises korralduses kasutati traditsioonilisi komi ja vene õigeusu elemente. Algselt oli see kogudus baptistliku suunitlusega, mille keskmes oli piibli lugemine. Vassili Popov ${ }^{31}$ tõlkis ühemehetööna piibli komi keelde. Vassili pojad Daniil ja Pavel on jätkanud isa kiriku edendamise tööd, lisades teenistustesse nelipühilikke elemente nagu keeltes rääkimine. Sõktõvkari Popovide kogudus ${ }^{32}$ on üks väheseid rahvuslikke kirikuid soomeugrilaste seas Venemaal, kus prioriteetne on oma keel (vene koguduse liikmetele tõlgitakse tagareas komi keelest vene keelde). Keeleideoloogiliselt on oluline idee, et omakeelsus võimaldab Jumalat paremini mõista. Lisaks sellele praktilisele küljele esitatakse ka teoloogiline põhjendus: kümnes käsus esinev esivanemate austamise nõue tähendab ühtlasi nõuet austada esivanemate keelt (Bourdeaux, Filatov 2005: 193-195; Leete 2013: 258-261, 270).

Ingeri Kirik sai Komimaal jala ukse vahele, kui Arvo Survo ja Juha Väliaho külastasid Sõktõvkari 1996. aastal. Selle tulemusel tekkis Komimaal kaks aastat hiljem kaks kogudust (Väliaho 2004: 100-101). Filatov osutab, et komi rahvuslikus liikumises Kaitseme End (komi Дорьям асьнымос) oldi kahevahel, kas valida "paganluse“ restaureerimine või kristlus. Väidetavalt otsustati kristluse kasuks pärast seda, kui Arvo Survo veenis liikumise liidrit Nadežda Mitjuševat luterlusse pöörduma. Filatov teatab, et poliitiline liikumine muutus religioosseks kogukonnaks, mis venelaste liitudes kaotas oma rahvusliku eripära: „... isegi rahvuslane Mitjuševa oli sunnitud nõustuma paralleelse venekeelse jumalateenistusega" (Bourdeaux, Filatov 2005: 190; vt ka Filatov 2016: 384). ${ }^{33}$ Komi rahvusest Sõktõvkari

[31] Popov käis korduvalt Eestis, kus ta konsulteeris keeleküsimustes Paul Aristega ja teoloogilistes küsimustes metodist Hugo Oengo ja baptist Árpád Arderiga, vt http://piibliselts. ee/ajakulg/piibliseltsi-korraline-aastakoosolek, vaadatud 30.11.2017. Aastal 1975 pühitses Oengo Tallinnas Popovi Komi Kiriku piiskopiks, vt http://www.elupuu.org/index_komi. php?id=213, vaadatud 30.11.2017.

[32] Sõktõvkari koguduses ja kuues tütarkoguduses on kokku alla 200 liikme (tuletatud Filatov 2016: 388-390 põhjal). Nad teevad koostööd Udmurdimaa, Soome ja Eesti misjonäridega ning sõidavad ka ühiselt kuulutustööl mööda komi külasid.

[33] Kui aastal 2000 oli Sõktõvkari Ingeri Kirikul kuni 100 liiget, siis sisetülide tõttu langes see 2004. aastal 20ni (Bourdeaux, Filatov 2005: 190). Aastal 2015 oli kirikus 40 liiget, „peamiselt kõrgema haridusega komid“" (Filatov 2016: 384). 
koguduse diakon Jelfimov teeb tihedat koostööd Saksa Kirikuga, kasutades muuhulgas viimase kirikuhoonet Sõktõvkaris. ${ }^{34}$

Mis puudutab VÕKi, siis on sealne piiskop Pitirim ja mõned teised teinud endast oleneva, et takistada protestantide edu, sealhulgas süüdistades neid selles, et nad on „viies kolonn“ ja nad võivad korraldada "oranži revolutsiooni“ (Filatov 2016: 383; vt ka Koosa 2017: 38). Lisaks on Pitirim heitnud kohalikele võimudele ette, et nood on liialt liberaalsed ega ole piisavalt protestantide tegevust takistanud. Samas leidub õigeusu vaimulikke, kellega on protestantidel võimalik suhelda ilma suuremate probleemideta. Nagu Mordva-, Mari- ja Udmurdimaalgi on viimasel ajal ka Komimaal õigeusklikud üha enam asunud komikeelseid teenistusi pidama. Filatov kirjutab, et „enamikus kogudustes kasutatakse liturgias kasvõi aeg-ajalt osaliselt komi keelt" ning kolmandik vaimulikest on komid, kuigi mitte kõik ei oska neist komi keelt (2016: 366). Käärid keeleoskuse ja rahvusliku enesemääramise vahel kasvavad.

\section{Protestantide käsitlus „paganlusest“ ja „paganatest”}

Millised on aga protestantide suhted Venemaa soome-ugri põlisusundite esindajatega? Kõige enam puudutab see küsimus just marisid, mingil määral aga ka udmurte..$^{35}$ Soome luterlik misjonär Juha Väliaho väidab, et „maride ja udmurtide loodususundi põhiolemus on hirm esivanemate hingede ees" (HA 2012 (8): 15). ${ }^{36}$ Ta maalib pildi, mille järgi maridel on vaimne vaakum, mis tuleb täita kristlusega:

Soome-ugri rahvaste loodususundi traditsioonid on hääbumas, mari külarahva teadmised tavanditest on väga napid. Selle asemel on maad võtmas vaimulik tühjus, loodususundi puudumist asendab sihitu eluviis ja vägijookide pruukimine. See tähendab meie sugulasrahvaste identiteedi järkjärgulist kadumist ja nende sulandumist teiste rahvastega, millele aitavad kaasa ka segaabielud teisest rahousest abikaasaga. (HA 2012 (8): 15; vt ka Väliaho 2004: 124-127; 173-174)

[34] Lisaks on komisid Sõktõvkari nelipühi kirikus Elu Allikas, kus tehakse väljaspool pealinna misjonitööd ja selle tulemusel on tekkinud komikeelseid kogudusi ja gruppe (Filatov 2016: 391-392). Kuigipalju komisid on ka nn registreeritud evangeelsete kristlaste baptistide seas (Filatov 2016: 386).

[35] VÕKi Iževski ja Udmurtia piiskopkonna kodulehel väidetakse et umbes 50000 ehk $6 \%$ kõigist udmurtidest „jäävad eelkristlike uskumuste järgijateks“ ehk siis "paganateks“. Nad elavalt peamiselt Baškiirias, Tatarstanis, Permi krais ja Sverdlovski oblastis. Udmurtias on neid vähemalt tuhat, peamiselt Alnaši, Kijasovo, aga ka Sarapauli ja Kambara rajoonis, kus elavad Baškiiriast ja Permi kraist välja rännanud udmurdid (http://arhiv.udmeparhia.ru/ translate/udm/udm_323.html, vaadatud 30.11.2017).

[36] Juha Väliaho (HA 2012 (7): 3; 2012 (8): 15) väidab, et Marimaa maride seas on kõik paganad, neist $60 \%$ on õigeusku ristitud ning ",nad on kaheusulised“. Idamaride seas aga on enamik ristimata (70-80\%) ja pea kõik on „,südames“ paganad. Ta kirjutab: „Volga jõe ääres Marimaal on peale kasvanud ohvripreestrite uus põlvkond, aga Uuralites, Baškiiria idamaride hulgas on traditsioon katkenud: ei ole enam ohvripreestreid, kes teaksid, kuidas vana tava järgi ohverdada“ (HA 2012 (8): 15). Ohvrirituaale jätkati siiski idamaride seas siin-seal kogu nõukogude aja jooksul (Sadikov 2016: 15). 
Väliaho kinnitab, et: „,selline olukord pakub soodsa pinnase teha kristlikku misjonitööd, viia evangeeliumi vaimuliku pimeduse keskele“ (HA 2012 (8): 15). Iseloomulikult esitab ta konversiooni kui päästeaktsiooni, millel on nii teoloogiline kui rahvuslik mõõde.

Vastuseis leiab äramärkimist harva. Anna Mišina, kes on Eestis ja Soomes elav mari ning kes osaleb idamaride misjonitöös, kirjutab:

Kõige suurem vastuseis kristlastele on mari paganliku usu järgijate poolt. Näiteks eelmainitud ristimisel avaldasid ristitud naise sugulased, naabrid ja tuttavad soovi osaleda pidulikul jõulujumalateenistusel Birskis. Pastoriga lepiti kokku, et transporti vajab 5-7 inimest, päev hiljem aga selgus, et nii mõnelgi soovijaist keelati omaste poolt end "sektantidega" siduda.

Paganausulised ei taha reeta esivanemate usku, arvates, et kristlus hävitab põlised traditsioonid ja kultuuri. Tegelik olukord on vastupidine: luterlik kirik püüab oma töös kasutada emakeelt ja säilitada kultuuritraditsioone. Koguduse liikmed laulavad kirikü̈ritustel rahvalaule, suurematel pühadel pannakse selga rahvarõivad. Kirikus on väike etnograafiamuuseum, kus asuvad nii koguduseliikmete ja misjonäride kogutud kirikuriistad kui ka rahvarõivad. Kogudusekooli jaoks on välja töötatud marikeelsed tunnid. (HA 2016 (16): 17)

Misjonärid üritavad kristlusesse pöördumist esitada lugejatele millegi sellisena, mis ei hävita „kultuuri“, vaid pigem päästab seda. Kristlike misjonäride käsitluses kultuurist on vormi küsimus, milles ei puudu oma analoogia nõukogude ajaga, mil oli keskne loosung „,sisult sotsialistlik, vormilt rahvuslik“. Vorm on laul, tants, rahvarõivad, mida kõike paigutatakse kultuuri alla. Nagu märgitakse: „,... muusika sobib maridele evangeeliumi kuulutamiseks suurepäraselt, kuna sel rahval on laul ja tants veres" (HA 2011 (6): 6). Kui lubatud on rahvariided ja rahvaviisid, siis on vorminõue täidetud, sisu peab olema aga kristlik (vrd Pelkmans 2007). ${ }^{37}$

Väidetakse, et rahvalike motiivide kasutamine eemaldab segava võõrapärasuse ja muudab kristluse atraktiivsemaks. Nii arutleb Arvo Survo selle üle, et hea on kasutada kohalikke vorme nagu regivärss kristliku sõnumi edastamiseks. Ta ütleb, et „,kui kristlikku sisu pakutakse võõras pakendis, pole rahvas sellega päri“ (HA 2012 (7): 8). Samas võtmes väidab Mark Nelson, et „,... paganluse kõrvaleheitmine ja tõelise Jumala poole pöördumine ei nõua selja pööramist oma päritolule ega kultuurile. Sa võid tõesti olla mari ja ühtlasi olla kristlane!“" (HA 2015 (14): 13). Mari, kes võib kanda rahvarõivaid ja tunda uhkust käsitöö ja laulude üle, peab aga loobuma ohvripalvustel osalemast, sest tegemist ei ole kultuuriga, pigem selle antiteesiga.

Vabakogudusi esindav Heigo Ausmees kirjeldab, kuidas kultuuritundlikult misjonit teha, ilma et kultuuri muudetaks euroameerikalikuks globaalseks kultuuriks:

Ma ei arva, et misjonitöö eesmärgiks oleks ühe rahva kultuuri muutmine. Misjon, mille eesmärk on õpetada "metslasele" torukübara kandmist, jäägu 19. sajandisse. Misjoni eesmärk väikerahvaste juures on õpetada inimest läbi Kristuse oma juuri leidma, taasavastama oma rahvakultuuri ning selle üle uhke olema. Usun, et Kristus sobib igasse kultuurikeskkonda ega pü̈̈a seda lahustada lahjaks euroameerika süldiks, vaid aitab kultuuri omapära ning tugevust välja tuua. (HA 2006 (1): 6)

[37] Olen mujal kirjutanud pikemalt sellest, kuidas vene fundamentalistlikud misjonärid väidavad, et nad ei muuda kultuuri, vaid viivad üksnes usku neenetsitele (Vallikivi 2014). 
Juurte leidmine ei tähenda religioossete juurte otsimist ajaloost, sest seal saab asuda üksnes „paganlus“. Misjonäride eesmärk on aidata kaasa kultuurilisele „,arengule“, mida esitatakse justkui paratamatusena. Ausmees väidab, et ei muudeta kultuuri, vaid muudetakse selle antiteesi, mida ta nimetab „,surmakultuuriks":

Teiselt poolt on igas kultuuris "surmakultuur," mis hävitab ja hukutab selle kandjad. Sellele astub kristlus otsustavalt vastu ning muundab ta elujaatavaks, edasiviivaks. Ükski kultuur ei ole igavene ja muutumatu. Nagu iga elusolend, areneb ka rahvas ja tema kultuur. Status quo on talletatav, kuid mitte säilitatav. Ühes asjas oleme antropoloogidega ühel nõul: me mõlemad loodame, et väikerahvad ja nende kultuur jäävad püsima. (HA 2006 (1): 6)

Kultuuriantropoloogide seisukohast on kultuur - hoolimata mõiste ülimast problemaatilisusest - keskne mõtestamaks eri rahvaste ja gruppide usundilisi süsteeme. Sageli defineeritakse usundi kaudu laiemat kultuuriliste mustrite kogumit. Pealegi esindab kohalik usund mitmekesisust, millesse usuvad antropoloogid. Nendes küsimustes on antropoloogidel ja misjonäridel pikk eriarvamuste ajalugu (Vallikivi 2014: 96).

Ka keel ei pääse vormi ja sisu dihhotoomiast, eriti kui vorm trotsib sisu. Märgiline on debatt näiteks Udmurtias, kus nelipühi muusikaline evangelismigrupp võttis endale nimeks Kõldõšin. Udmurtide jaoks on Kõldõsin (või Kõltšin) oluline usunditegelane, kes seostub loomisega. Ja samas on siin kristlaste väitel viide inkarneerunud Kristusele, kuivõrd sõna etümoloogia viitavat sellele. Metodist Nelson, kes kommenteerib tekkinud pinget, kirjutab:

Kõldõšin on udmurdi rahousliku religiooni jumalik olend. Sõna ise tähendab "taevastes riietunud sõna" (kõl = sõna, dõs = riie, in = taevas) ja legendi järgi rõivastas Kõldõšin-sõna end ja kõndis Udmurtias ringi valgesse riietatud mehena. (HA 2009 (4): 6)

Nime „Kõldõšin“ paneb ette Filadelfia nelipühi koguduse mitteudmurdist pastor. Udmurtidest grupiliikmed aktsepteerivad seda, kuna see rõhutab nende sõnul seost udmurdi keele ja kultuuriga. Seda peetakse ligitõmbavaks ka potentsiaalsetele huvilistele. Leidub aga ka neid, kes on selle vastu, kuna see olla „paganliku“ jumala kummardamine. Nelson, kes udmurdi religiooniuurijate töid ei loe, aga loeb piibliuurijate tekste, arutleb oma kommentaaris kaananlaste „paganausu“ mõju üle iisraellaste ainujumalausule ning leiab, et vormi laenamine kristluses ei ole patt: "Jumal on tegelikult kultuuriliselt tundlik misjonär!“ Ta toob näiteid, kuidas „paganlike" jumalanimesid on kasutatud Jahve kohta. Samuti soovitab Nelson kasutada kristliku jumala kohta udmurdi taevajumala nime "Inmar" ja mitte vene "Bog" (seda teeb muide ka Atamanov oma piibli tõlkes ja nime "Inmar" kasutati ka 18. sajandi lõpust alates kristlike tekstide tõlgetes, vt Kamitova 2017: 45, 88-89, 111).

Kui vaadata aga, mida religiooniuurijad ja lingvistid kirjutavad, siis sõna kõldõsin (кылдысин, mitte кылдышин) etümoloogia ei ole sugugi nii selge, nagu Nelson seda esitab. Sõna kõldõnõ (кылдыны) tähendab „looma“, "viljastama“. Vladõkin, osutades soome lingvist Uotila tööle, väidab, et in (ин) on vanapermi algega ning tähistab naist: seega tegemist võib olla hoopis naise loova väega (Vladõkin 1994: 103, 181). Lisaks on Kõldõsini üheks variandiks tegelane, kes elab maa all (vahel ka nimega Mukõldõsin, vt Vladõkin 1994: 103). Need seigad teevad Kõldõsini nime tähendusvälja positiivse hõlvamise kristlaste poolt veelgi keerulisemaks. Ilmselt 
jõuab nende vastuolude ulatus lõpuks ka nelipühilasteni ja evangeelse muusikagrupi nimi muudetakse Inkrez'iks, mida tõlgitakse kui „,taeva meloodia“ (HA 2010 (5): 17). See juhtum illustreerib muuhulgas seda, et kristlikus mõtlemises domineeriv sisu ja vormi vastandus on paratamatult määratud läbikukkumisele.

\section{Kokkuvõte}

Kui Nõukogude Liidu lagunemine toob kaasa ulatusliku misjonitegevuse Venemaal, ühinevad sellega ka Eestist ja Soomest pärit protestandid (peamiselt luterlased, metodistid, baptistid, nelipühilased), kes asuvad aktiivselt usku kuulutama Venemaa soome-ugri rahvaste seas. Kuivõrd eestlasi ja soomlasi võetakse sageli vastu ",sugulastena“, siis näevad misjonärid selles „Jumalast antud nišši“, mida ära kasutada. Misjonäride eesmärk on luua kristlik sugulus, kus hõimuvennad ja -õed saavad usuvendadeks ja -õdedeks. Hoolimata vastupidistest süüdistustest peavad nad oma ettevõtmist soome-ugri kultuure ja keeli päästvaks, lähtudes püüdest tuua idapoolseid „hõimurahvaid“ lähemale eestlaste ja soomlaste protestantlikele maailmadele ja lunastusele.

Protestantlikud Eesti ja Soome misjonärid esitavad end kohalike keelte alalhoidjatena. Praktikas on aga nende tegevus üsna vastuoluline. Ühelt poolt rõhutatakse emakeelsete religioossete tekstide kättesaadavuse vajadust, osaletakse kristlike tekstide tõlketöö korraldamises ning soositakse kohalikku omakeelset misjonit. Teisalt ei ole hõimumisjoni praktikas esimeseks keeleks kohalik keel, vaid vene keel, kuna vene keele oskus on soomeugrilaste seas valdav (olgugi et mitte alati samal tasemel kui venelastel). Kuna esmane ülesanne on võimalikult palju inimesi kristlusesse pöörata, siis ei ole kohaliku keele õppimine misjonäride jaoks esmatähtis. Vastandlike väärtushoiakute ja praktiliste valikute tõttu tekib emakeelseid kogudusi vähe.

Eesti ja Soome protestandid esitavad end kohalike kultuuride päästjatena. Eeskuju andvaks mudeliks võtavad nad eesti ja soome kristlikud rahvakultuurid, kus „paganluse“ roll on justkui kontrolli all ja rahvakultuuri elemendid on osa kultuurilisest tervikust. Misjonär toodab kujutlust kultuurist kui millestki, mida saab riietada, laulda ja süüa, millestki, mis ei suhestu peremeesvaimude või esivanemate hingedega, kellega suhtlemise käigus on oluline osa nähtavast kultuurist loodud. Kokkuvõtvalt võib tõdeda, et kristianiseerimise kultuuri muutev jõud toimib seda tugevamini kui kultuuri muutmist eitada.

Puhastades „kultuuri“ mõiste alt animistlikud ehk „paganlikud“ traditsioonid, satuvad protestandid vastuollu soome-ugri identiteeti väärtustatavate liikumistega, kes näevad ühisosa „kristluse-eelses“ kultuuris (näiteks nagu „(uus)paganad“, vt ka Kuutma 2005; Västrik 2015) ja kelle jaoks kristlus etendab kultuuri hävitavat rolli. Teatud analoogia on siin ka suhetes vene õigeusklikega ja iseäranis VÕKiga, kes peab protestante põlistele ortodokssetele aladele sissetungijateks ja kohaliku kultuuri hävitajateks. Mõlemal juhul on tegemist aktiivse võitlusega oma keele ja kultuuri kontseptsioonide ja nende kehtestamise pärast, mille tulemusel on nii mõnegi soome-ugri kogukonna elu kardinaalselt muutumas. 


\section{Kirjandus}

Aitamurto, Kaarina. 2016. Paganism, Traditionalism, Nationalism: Narratives of Russian Rodnoverie. London: Routledge.

Alõbina 2017 = Алыбина, Татьяна. 2017. Трансформацция марийской религиозной традициии в постсоветский период. Tartu: University of Tartu Press. Veebiversioon: http://dspace. ut.ee/Handle/10062/58075, viimati külastatud 30.11.2017.

Atamanov 1999 = Атаманов, Михаид Г. 1999. Мой путь в Библию. Ижевск.

Ben-Dor Benite, Zvi. 2009. The Ten Lost Tribes: A World History. Oxford: Oxford University Press.

Bogatova 2015 = Богатова, Ольга. 2015. Конструирование сакрального социального пространства эрзянского неоязыческого ритуала: религиозные и политические практики. - Сергей В. Соколовский (отв. ред.). Инновациии в антропологии. Новые направления, объекты и методы в российских антропологических исследованиях. Москва: ИЭА РАН, 59-81.

Bourdeaux, Filatov 2005 = Бурдо, Майкл; Филатов, Сергей Б. (отв. ред.). 2005. Атлас современной религиозной жизни России. Том 1. Москва: Детний сад.

Bourdeaux, Filatov 2006 = Бурдо, Майкл; Филатов, Сергей Б. (отв. ред.). 2006. Современная религиозная жизнь России. Опыт систематического описания. Том IV. Москва: Аогос.

Dušenkova 2013 = Душенкова, Татьяна Р. 2013. Понятие оскон „вера; надежда“" в удмуртском языке и его трансформации. - Филологические науки. Вопросы теории и практики, 12 (30): 81-84.

Evanõn-Birski 2009 = Эванын-Бирский, Илья. 2009. Помощник жреца: финны - недруги марийского народа. - MariUver. https://mariuver.com/2009/06/25/finny-nedrugi/ (viimati külastatud 30.11.2017).

Filatov 2016 = Филатов, Сергей Б. (науч. ред.). 2016. Религиозно-общественная жизнь российских регионов. Том II. Москва: Детний сад.

Filatov 2017a = Филатов, Сергей Б. 2017а. Православие мордовских народов перед языческим и протестантским вызовами. - О. П. Бибикова, Н. Н. Цветкова (отв. ред.). Труды Института востоковедения РАН. Выпуск 4. Экономические, социальнополитические, этноконфессиональные проблемы афро-азиатских стран. Москва: ИВ РАН, 291-302.

Filatov 2017b = Филатов, Сергей Б. 2017b. Национальное движение марийского народа: между язычеством и христианством. - О. П. Бибикова, Н. Н. Цветкова (отв. ред.). Труды Института востоковедения РАН. Выпуск 4. Экономические, социальнополитические, этноконфессиональные проблемы афро-азиатских стран. Москва: ИВ РАН, 270-290.

HA 2006-2017 = Hõimurahvaste Aeg, 2006-2017 (1-18). Veebiversioon: http://hoimurahvad. misjon.ee/ (viimati külastatud 30.11.2017).

Kaldur, Peeter. 2016. Hõimukirikute rahvusvahelise suhtluse ajalugu. - Eesti Kirik 30, 3. august, $1 \mathrm{k} 10 ; 31,10$. august, $1 \mathrm{k} 6 ; 32,17$. august, $1 \mathrm{k} 10 ; 33,24$. august, $1 \mathrm{k} 6$.

Kamitova 2017 = Камитова, Алевтина В. Переводная литература христианского просвещения на удмуртском языке XIX - начала XX в. История развития, жанровое своеобразие и переводческие стратегии. Ижевск: Шелест.

Kljašev 2013 = Кляшев, Александр Николаевич. 2013. Протестантизм Республики Башкортостан. Социальная реакция на вызовы современности. Уфа: Здравоохранение Башкортостана.

Koosa, Piret. 2017. Negotiating Faith and Identity in a Komi Village: Protestant Christians in a ProOrthodox Sociocultural Environment. Tartu: University of Tartu Press. 
Kuutma, Kristin. 2005. Vernacular religions and the invention of identities behind the FinnoUgric wall. - Temenos: Nordic Journal of Comparative Religion 41 (1): 51-76.

Laakso, Anita; Aduškina, Nina. 2008. Ei ainoastaan leivästä: ersämordvalainen raamatunkääntäjä Nina Aduškina muistelee. Helsinki: Raamatunkäännösinstituutti.

Leete $2013=$ Аеэте, Арт. 2013. «Бог говорит на моем родном языке»: этническая стратегия Коми церкви. - Антропологический форум 18: 256-275.

Lindquist, Galina. 2006. Conjuring Hope: Magic and Healing in Contemporary Russia. New York: Berghahn Books.

Luehrmann, Sonja. 2012. Secularism Soviet Style: Teaching Atheism and Religion in a Volga Republic. Bloomington: Indiana University Press.

Lunkin, dateerimata = Дункин Роман. Интервью с переводчиком Библии на удмуртский язык диаконом Михаилом Атамановым. http://www.keston.org.uk/russia/articles/ rr23/01interview.html (viimati külastatud 30.11.2017).

Mišina 2016 = Mishina, Anna. 2016. Ristiusu ja traditsioonilise usundi piiril: sünkretism luterlikus kirikus idamaride seas. - Ave Goršič, Piret Koosa (koost.). Noorte hääled: noorte etnoloogide ja folkloristide konverents. Tartu, 20. aprill 2016. Eettekannete kokkuvõtted. Tartu: Eesti Rahva Muuseum, Eesti Kirjandusmuuseum, 20-21.

Nelson, Mark. 2009. Estonia's Finno-Ugric mission: developing a God-given niche. - The East-West Church \& Ministry Report 17 (1). http://www.eastwestreport.org/30-english/e17-1/228-estonia-s-finno-ugric-mission-developing-a-god-given-niche (viimati külastatud 30.11.2017).

Pelkmans, Matthijs. 2007. 'Culture' as a tool and an obstacle: missionary encounters in postSoviet Kyrgyzstan. - Journal of the Royal Anthropological Institute 13 (4): 881-899.

Pienoisevankeliumi 2015 = Pienoisevankeliumi Inkerin kirkon jumalanpalveluskielillä. 2015. - Inkerin Kirkko 96 (4): 18-19.

Prozes, Jaak. 2015. Maride ja mordvalaste rahouslikud organisatsioonid 1980ndate lõpul ja 1990ndate alguses. Bakalaureusetöö. Tartu: Tartu Ülikool. Veebiversioon: http://dspace.ut.ee/handle/10062/48605, viimati külastatud 30.11.2017.

Raudalainen, Taisto. 2014. Oma maa ubina äitsen: ingerisoomlased 20. sajandil. Tallinn: Argo.

Rock, Stella. 2007. Popular Religion in Russia: 'Double Belief' and the Making of an Academic Myth. London: Routledge.

Romanova, Evgenia. 2007. The Process of Revitalization of Culture and Indigenous Ethnic Identity: The Case of the Vepsian People in Karelia. Master Thesis. Tromsø: University of Tromsø. Veebiversioon: https://munin.uit.no/bitstream/handle/10037/1156/thesis.pdf?sequence=4 (viimati külastatud 30.11.2017).

Sadikov 2016 = Садиков, Ранус Р. 2016. Финно-угорские народы Республики Башкортостан (история, культура, демография). Уфа: Первая типография.

Soom, Kaido. 2016. Ingeri kirik ootab soome-ugri vaimulikke konverentsile. - Eesti Kirik 1, 6. jaanuar, lk 4-5. Veebiversioon: http://www.eestikirik.ee/ingeri-kirik-ootab-soome-ugrivaimulikke-konverentsile/ (viimati külastatud 30.11.2017).

Zagrebin, Išmuratov, Kirillova 2011 = Загребин, А. Е.; Ишмуратов, А. В.; Кириллова, Р. В. (сост.-ред.). 2011. Этногенез удмуртского народа. Этнос. Язык. Культура. Религия. Сборник статей и материалов Международной научной конференцзии, посвященной 65-летию доктора филологических наук, ученого-филолога, автора эпоса «Тангыра», переводика Библии на удмуртский язык, члена Союза писателей России Атаманова Михаила Гавриловича. Ижевск: Удмуртский университет.

Zamyatin, Konstantin. 2013. Sovereignisation and state languages: early formation of language policy of Russia's Finno-Ugric Republics in the conditions of the USSR disintegration. - Finnisch-Ugrische Mitteilungen 36: 123-165. 
Tervonen, Heikki. 2007. Arvo Survon matkassa Viipurista Volgan mutkaan. Helsinki: Kirjapaja. Toompuu, Tauno. 2009. Milline on misjonäri hind? - Eesti Kirik 5, 4. veebruar, lk 5. Veebiversioon: http://www.eestikirik.ee/milline-on-misjonari-hind/ (viimati külastatud 30.11.2017).

Toulouze, Eva; Vallikivi, Laur. 2016. The Sacred places of the Bashkortostan Udmurt. Ежегодник финно-угорских исследований. Yearbook of Finno-Ugric Studies 10 (3). Ижевск: Удмуртский университет, 146-155.

Vallikivi, Laur. 2005. Arktika nomaadid šamanismi ja kristluse vahel: Jamb-to neenetsite pöördumine baptismi. Tartu: Tartu Ülikooli Kirjastus.

Vallikivi, Laur. 2009. Christianisation of words and selves: Nenets reindeer herders joining the state through conversion. - Matthijs Pelkmans (ed.). Conversion after Socialism: Disruptions, Modernities and the Technologies of Faith. Oxford: Berghahn, 59-83.

Vallikivi, Laur. 2011. What does matter?: Idols and icons in the Nenets tundra. - Journal of Ethnology and Folkloristics 5 (1): 75-95.

Vallikivi, Laur. 2014. On the edge of space and time: Evangelical missionaries in the tundra of Arctic Russia. - Journal of Ethnology and Folkloristics 8 (2): 95-120.

Vallikivi, Laur. 2018. Des Finno-ougriens convertissent des Finno-ougriens: foi, parenté et langue dans la rencontre missionnaire. - Etudes finno-ougriennes 49. (ilmumas)

Vladõkin 1994 = Владыкин, Владимир Е. 1994. Религиозно-мифологическая картина мира удмуртов. Ижевск: Удмуртия.

Vorontsov, Tšernijenko 2015 = Воронцов, В. С.; Черниенко, Д. А. 2015. Удмуртская Республика. Межэтнические и религиозные отношения под вдиянием социальноэкономических проблем и «передела» власти. - В. А. Тишков, В. В. Амелин, В. В. Степанов (ред.). Межэтнические отношения и религиозная ситуациия в Приволжском федеральном округе. Экспертный доклад за 2015 год. Москва-Оренбург: Университет, 151-168.

Väliaho, Juha. 2004. Volgan ja Uralin välillä: lähetystyötä suomalais-ugrilaisten kansojen keskuudessa. Helsinki: Suomen lähetysseura.

Västrik, Ergo-Hart. 2015. In search of genuine religion: the contemporary Estonian maausulised movement and nationalist discourse. - Contemporary Pagan and Native Faith Movements in Europe: Colonialist and Nationalist Impulses. New York: Berghahn Books, 130-153.

Wiget, Andrew; Balalaeva, Olga. 2007. Crisis, conversion, and conflict: evangelical Christianity, rapid change, and the Eastern Khanty. - Sibirica 6 (1): 1-29.

Laur Vallikivi (PhD) on Tartu Ülikooli etnoloogia vanemteadur. Tema peamine uurimishuvi on seotud Venemaa põhjarahvaste religioonide ning nende muutumisega väliste mõjurite survel. Ta on avaldanud monograafia „Arktika nomaadid šamanismi ja kristluse vahel“" (2005) ning artikleid neenetsitest, udmurtidest ja jukagiiridest. 


\section{Summary: Faith-based Finno-Ugric outreach: Estonian Christian missionaries among kindred peoples in Russia}

\section{Laur Vallikivi}

This article provides an initial overview of the role of Christianity in the Finno-Ugric movement and the instrumentalisation of Finno-Ugric identity. It analyses the mission activity conducted by Estonians (and Finns to some extent) among speakers of Finno-Ugric (Uralic) languages in Russia. Above all, the writings of missionaries are used as the source - primarily mission publications published in Estonia. The background is the author's fieldwork conducted among Nenets reindeer herders, who have been influenced by Russian and Ukrainian Protestant missionaries, and the Udmurt people living on the far side of the Kama, the latter being untouched by mission work. In both communities, religion and language inherited from forebears have a noteworthy role, even though the younger generation is becoming equally bilingual (the Russian language often dominates) and fewer and fewer young people take part in the non-Christian rituals passed down by their ancestors.

The first half of the article gives an overview of how the church's outreach directed at peoples who speak Finno-Ugric languages (hõimumisjon and hõimutöö are Estonian terms used) developed and the ideology behind it. The second half focuses on the activities of Estonian and Finnish missionaries in Russia. The author looks at the reception that the Erzya and Moksha Mordvins, Mari, Udmurts and Zyrian Komis have given the missionaries and also examines Protestant relations with the Russian Orthodox Church and representatives of local native religions.

Whereas the collapse of the Soviet Union saw extensive missionary activity in Russia, Protestants from Estonia and Finland (mainly Lutherans, Methodists, Baptists and Pentecostals) set out to actively spread the gospel among Finno-Ugric peoples living in Russia. As Estonians and Finns are often accepted as 'kin', missionaries see this as a 'niche provided by God', which should be utilised. The goal for the missionaries is to create a Christian community where the kindred brothers and sisters become religious brethren. In spite of accusations to the contrary, they consider their endeavour something that will save Finno-Ugric cultures and languages, proceeding from the attempt to bring eastern 'kindred peoples' closer to the Protestant world and the world of the Estonians and Finns and the possibility of redemption.

Protestant Estonian and Finnish missionaries portray themselves as preservers of the local languages. In practice, however, their activities are quite conflicting. On one hand, the need to make religious texts available in native languages is stressed, and they participate in organising translation of Christian texts and promote the local mission in the indigenous languages. On the other hand, the primary language used for outreach is not the local language but Russian, as Russian proficiency is predominant among Finno-Ugrians (although not always on a par with that of Russians). As the primary objective is to convert as many people as possible to Christianity, it is not of primary importance for missionaries to learn the local language. 
Due to conflicting values and practical choices, few native-language congregations are created.

Estonian and Finnish Protestants style themselves as preservers of local cultures. The role model is that of Estonian and Finnish Christian popular cultures where the role of 'paganism' is under control and the elements of national culture tend to be integrated into a cultural whole. Missionaries cultivate an image of culture as something that can be dressed, sung, eaten, but not as something that relates to the house guardian spirits or the souls of ancestors, communicating with whom is a factor underlying the creation of a major part of the visible culture. To sum up, the author asserts that Christianisation as a culture-changing force has all the more powerful an effect if cultural changes are resisted. 


\section{Резюме: Финно-угорская миссия: деятельность эстонских христиан среди родственных народов в России}

\section{Лаур Валликиви}

В настоящей статье представлен первичный обзор роди христианства в финноугорском движении и инструментадизации финно-угорского идентитета. Анализируется направляемая из Эстонии (и в некоторой степени из Финляндии) миссионерская деятельность в России среди народов, говорящих на финно-угорских (уральских) языках. Источником служат, прежде всего, публикации миссионеров, в основном издаваемые в Эстонии миссионерские журналы.

Основой статьи послужили полевые исследования автора среди ненцеволеневодов, подвергшихся влиянию русских и украинских протестантских миссионеров, и среди закамских удмуртов, не затронутых христианским миссионерством. В обеих общинах значительную родь играют унаследованные от предков вера и язык, несмотря на то, что молодое поколение все больше становится двуязычным (русский язык часто доминирует) и все меньше молодежи участвует в унаследованных от предков нехристианских ритуалах.

Первая часть статьи предлагает обзор возникновения и основной идеологии миссии, направленной на говорящие на финно-угорских языках народы (финно-угорская миссия, племенная миссия). Вторая часть сосредотачивается на деятельности эстонских и финских миссионеров в России. Автор рассматривает, как воспринимают проповедников эрзя, мокша, мари, удмурты и коми-зыряне, а также анализирует отношения протестантов с Русской православной церковью (РПЦ) и представителями местных религий.

Когда распад Советского Союза повлек за собой широкую миссионерскую деятельность в России, то к ней присоединились и протестанты из Эстонии и Финляндии (в основном дютеране, методисты, баптисты, пятидесятники), которыеприступиликактивномупроповедованиюверысреди финно-угорских народов России. Поскольку эстонцев и финнов часто воспринимают «как родственников», то миссионеры видят в этом «богом данную нишу», которой следует восподьзоваться. Целью миссионеров является создание христианского родства, при котором родственные по языку братья и сестры станут братьями и сестрами по вере. Несмотря на обвинения в противоположном, они считают свое предприятие спасением финно-угорских культур и языков, объясняя это стремлением приблизить восточные «родственные племена» к эстонскому и финскому протестантскому миру и искуплению. Миссионеры-протестанты из Эстонии и Финдяндии выступают в роли хранителей местных языков. На практике их деятельность достаточно противоречива. С одной стороны, они подчеркивают необходимость доступности религиозных текстов на родном языке, активно участвуют в организации перевода христианских текстов и покровительствуют местным миссиям на родном языке. С другой стороны, в миссионерской практике среди финно-угорских народов первым языком явдяется не местный язык, а русский, поскольку среди финно-угров 
преобладает владение русским языком (пусть даже не всегда на том же уровне, что и у русских). Поскольку первичной задачей является обращение как можно большего кодичества людей в христианство, то изучение местного языка не является для миссионеров первостепенным. Из-за противоречивых ценностных установок и практических выборов, редигиозных приходов с родным языком общения появляется мало.

Эстонские и финские протестанты представляют себя в качестве спасителей местных культур. За образец культуры они берут эстонскую и финскую христианские народные культуры, в которых роль «язычества» находится как бы под контролем, а элементы народной культуры интегрированы в культурное целое. Миссионер создает из культуры некий образ, который можно одеть, спеть, съесть, но который не соотносится с духами-домовыми иди душами предков, общение с которыми играет важную родь в создании видимой культуры. Подводя итог, автор признает, что сила христианского преобразования культуры действует сильнее, нежели отрицание изменения культуры. 